\title{
ARTICLES
}

\section{SCIENTIFIC ISSUES AND THE FUNCTION OF HEARING PROCEDURES: EVALUATING THE FDA'S PUBLIC BOARD OF INQUIRY}

\author{
SIDNEY A. SHAPIRO*
}

I. Scientific Disputes AND the Function Of HeARing Procedures .................................... 290

A. The Nature of the PBOI Procedures .............. 290

B. The Nature of Scientific Evidence.................. 291

1. Animal and Clinical Data .................... 292

2. Epidemiological Data ....................... 294

C. The Nature of Hearing Procedures ................ 295

D. The Nature of Scientific Participation............... 299

1. The Rationale for Scientific Participation .......... 299

2. Effect of Scientific Participation on the Hearing Model ..................................... 301

3. The Rationale for the PBOI ................. 304

II. Applications of the PBOI Procedure............. 307

A. The "Aspartame" Case ......................... 307

1. Pre-Hearing Process ....................... 308

2. Hearing Process........................... 309

3. Post-Hearing Process ........................ 310

B. The "Depo-Provera" Case ..................... 313

1. Pre-Hearing Process ........................... 314

2. Hearing Process........................... 315

3. Post-Hearing Process ...................... 316

* Professor of Law, University of Kansas. B.S., 1970, J.D., 1973, University of Pennsylvania. An earlier version of this article was submitted to the Administrative Conference of the United States by the author as consultant. The publication of this article is authorized by the Conference, but the author is solely responsible for its contents. Support from the University of Kansas Research Fund facilitated this study. The author would like to thank those members of the Administrative Conference Staff, particularly David Pritzker, Dean Richard Merrill, and those colleagues, Robert Glicksman, Phillip Kissam, and Peter Schanck, who offered helpful comments on earlier drafts. The author would also like to acknowledge the substantial assistance of Tanya Treadway, Class of 1987, University of Kansas School of Law. 
III. Analysis of the Process $\ldots \ldots \ldots \ldots \ldots \ldots \ldots \ldots \ldots, 318$

A. The Pre-Hearing Process ...................... 318

1. Choice of the PBOI ........................ 318

2. Formulation of the Issues................... 320

3. Selection of Board Members .................. 324

a. Identifying qualified board members .......... 324

b. Selecting board members .................. 326

4. Other Pre-Hearing Procedures ................. 327

B. The Hearing Process ........................ 330

1. Quality of the Process ...................... 330

2. Flexibility of the Process ..................... 334

3. Open Nature of the Process ................... 334

C. The Post-Hearing Process ....................... 335

1. Time Delays ........................... 335

2. Inattention to Traditional Procedures ............ 338

3. Appropriate Standard of Review................ 339

IV. Future of the Public Board of InQuiry ........... 341

A. The PBOI Process at the FDA................. 341

B. The PBOI at Other Agencies ................... 342

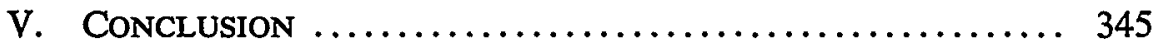

Finding effective decision-making techniques for scientific disputes has been one of the most elusive problems for the administrative process. ${ }^{1}$ Many scientists and others have supported the idea of a "science court"-a panel to which administrative agencies can refer scientific disputes for resolution by experts. ${ }^{2}$ In response, the Food and Drug Administration has developed a umque procedural mechanism, the Public Board of Inquiry (PBOI), to address such questions. The PBOI consists of a panel of three scientists and performs the role of an administrative law judge in the agency's hearing process. Hearings before the PBOI resemble a "scientific semmar"-most of the traditional hearing procedures are eliminated, including the direct participation of lawyers. ${ }^{3}$

FDA has held two PBOI proceedimgs. In 1980, a PBOI was convened to determine whether aspartame, a widely used artificial sweetener sold under the brand name NutraSweet, should be hicensed as a food additive. ${ }^{4}$ In 1983, a PBOI was convened to determine whether depo-

1. See Carrow \& Nyhart, Introduction, in LAW AND SCIEnCE In Collaboration: Resolving Regulatory Issues of Science AND Technology 1 (M. Carrow \& J. Nyhart eds. 1983) [hereinafter LAW AND SCIENCE IN COLlaboration].

2. See infra notes $88-100$ and accompanying text.

3. See infra notes $21-23,76-78$ and accompanying text.

4. See infra notes 133-93 and accompanying text. 
provera, a new drug approved as a contraceptive in practically every country except the United States, should be licensed for that use. ${ }^{5}$ This article examines the PBOI procedure to assess its usefuiness.

\section{SCIENTIFic Disputes AND the Function of Hearing Procedures}

\section{A. The Nature of the PBOI Procedures.}

The federal Food, Drug and Cosnetic Act (FDCA) ${ }^{6}$ requires the FDA to hold a "formal evidentiary hearing" to resolve any controversy concerning the approval of food additives and new drugs. ${ }^{7}$ This hearing constitutes formal adjudication under the Administrative Procedure Act. ${ }^{8}$ Since 1976, the FDA has offered parties entitled to a formal evidentiary hearing the alternative of choosing one of three informal methods for resolving their disputes: a hearing before a PBOI, ${ }^{9}$ a hearing before an advisory committee, ${ }^{10}$ or a hearing before the commissioner of the FDA. ${ }^{11}$

The commissioner will grant such a party's request for a PBOI when "it is in the public interest."12 Any person nay become a participant $\mathrm{n} 1$ the PBOI by filing a notice of intent. ${ }^{13}$ The commissioner then selects three scientists fron 1 persons the participants nominate to serve as a three-member hearing board; ${ }^{14}$ lie must choose one member from nonimations submitted by the FDA staff or from those submitted by the party that sought the PBOI, ${ }^{15}$ and a second from the nominations submitted by the other participants in the hearing. ${ }^{16}$ The commissioner may appoint any qualified person to serve as the third member and chairperson. ${ }^{17}$ All niembers of the board nuust have "medical, technical, scientific, or other qualifications relevant to the issues to be considered."18

5. See infra notes 194-240 and accompanying text.

6. 21 U.S.C. $\S \S 301-392$ (1982).

7. Id. $\S 348(f)$; id. $\S 355$ (c)(1)(B) (Supp. II 1984).

8. 5 U.S.C. $\$ \S 551-559,701-706$ (1982); see R. PIERCE, S. Shapiro \& P. VERKuIL, AdMINISTrative LAW AND Process $\$ 6.4 .2$ (1985).

9. 21 C.F.R. $\$ \$ 13.1-.50$ (1985).

10. Id. $\S \S 14.1-.174$.

11. Id. $\S \S 15.1-.45$.

12. Id. $\S 13.1$ (a). The PBOI process starts with a hearing notice published in the Federal Register. Id. $\S 13.5$.

13. Id. $\S 13.5(\mathrm{a})(2)$.

14. Id. $\$ 13.10$.

15. Id. $\S 13.10(\mathrm{c})$.

16. Id.

17. Id. Participants in the PBOI may also agree to an alternative method of selecting the board. Id. $\S 13.10(\mathrm{~d})$.

18. Id. $\S 13.10(\mathrm{a})$. 
A PBOI decision has the same legal status as the "initial decision" of an ALJ.19 Further, both the requirement of separation of functions and the prohibition against ex parte contacts apply to the PBOI. ${ }^{20} \mathrm{Nev}-$ ertheless, the FDA requires that "proceedings of a Board [be] conducted as a scientific inquiry rather than a legal trial."21 Thus participants may make uninterrupted oral presentations, and only the panel may question the witnesses, ${ }^{22}$ although participants may comment briefly on the presentations and may suggest questions to the board. ${ }^{23}$ The board may also ask FDA-paid consultants of its choice to present data at the hearing. ${ }^{24}$ At the conclusion of the hearing, participants may submit written statements of their positions with proposed findings and conclusions. ${ }^{25}$

The PBOI procedure involves a substantial departure from a conventional hearing 26 - the roles of lawyers and of the advocacy process are minimized in favor of a "scientific forum." Evaluating this deemphasis of adversary techniques requires consideration of the nature of scientific evidence, hearing procedures, and scientific input.

\section{B. The Nature of Scientific Evidence.}

Health and safety regulatory agencies are required to determine whether chemicals are sufficiently "safe" for human exposure or consumption. The FDA, for example, determines whether food and color additives are "safe"27 and whether drugs are "safe" and "effective."28 The Environmental Protection Agency, ${ }^{29}$ the Occupational Safety and Health Adinmistration, ${ }^{30}$ and the Consumer Product Safety Commission (CPSC) $^{31}$ make analogous scientific assessments. In determining the safety of chemicals, these agencies consider three sources of scientific evi-

19. Id. $\S 12.32(\mathrm{f})(1)$. The Board acts as an FDA consultant and is not subject to the Federal Advisory Committee Act. Id. $\$ 13.10(\mathrm{e})$.

20. Id. $\S 13.15$.

21. Id. $\S 13.30(\mathrm{a})$.

22. Id. $\S 13.30(\mathrm{c})$.

23. Id.

24. Id. $\S 13.30(\mathrm{f})$.

25. Id. $\S 13.30(\mathrm{e}),(\mathrm{i})$.

- 26. Because they are similar to a PBOI, hearings before advisory committees and the commissioner are also significant departures from a conventional hearing. See id. $\S \S 14.1-.55,15.1-.45$.

27. 21 U.S.C. $\$ \$ 348(c), 376(a)$ (1982).

28. 21 U.S.C. $\S 355($ b)(1) (Supp. II 1984).

29. The EPA monitors the safety of pesticides under the Federal Insecticide, Fungicide, and Rodenticide Act, 7 U.S.C. $\S \S 136-136 y$ (1982). (1982).

30. OSHA monitors the safety of exposure to chemicals in the workplace. 29 U.S.C. $\S 655$

31. The CPSC monitors potentially hazardous products marketed to the general public. 15 U.S.C. $\S 1262$ (1982). 
dence: ${ }^{32}$ experiments conducted to evaluate the effect on experimental animals; ${ }^{33}$ clinical experiments performed upon humans; ${ }^{34}$ and epidemiological studies evaluating the effect of prolonged exposure. ${ }^{35}$

To evaluate this type of scientific evidence, the agency must perform three assessments: data determination, data interpretation, and data extrapolation. ${ }^{36}$ The first involves determining the results of the experiments or studies. The second involves ascertaining the scientific significance of those results, which requires the agency to assess whether the methodology used in the studies was scientifically valid. In the third step, the agency predicts the consequences of human exposure to the chemical based on the results of studies considered to be valid.

The agency's determinations at each of these stages range from the purely factual-those that are capable of objective determination-to matters of judgment-those on which reasonable persons can disagree. Such "judgmental" conclusions can be "scientific"-requiring the application of scientific knowledge and experience-or "regulatory," requiring the apphication of legal or policymaking knowledge and experience. ${ }^{37}$ The degree to which a conclusion is factual or judgmental, and the nature of the judgment as scientific or regulatory, will differ depending on the source of the scientific evidence.

1. Animal and Clinical Data. In animal experimentation, investigators compare the health of animals in a "test" group with that of animals in a "control" group. Only the test group is administered the chemical being studied, but the experimenters select and maintain the

32. See McGarity \& Shapiro, The Trade Secret Status of Health and Safety Testing Information: Reforming Agency Disclosure Policies, 93 HARv. L. REv. 837, 868, n.157 (1980) (animal and human evidence used by FDA); Schroeder \& Shapiro, Responses to Occupational Disease: The Role of Markets, Regulation, and Information, 72 GEO. L.J. 1231, 1232-36 (1984) (animal and epidemiological evidence used by OSHA); Shapiro, Divorcing Profit Motivation from New Drug Research: $A$ Consideration of Proposals to Provide the FDA with Reliable Test Data, 1978 DukE L.J. 155, 157-58 (animal and human evidence used by FDA) [hereinafter Divorcing Profit Motivation]; Shapiro, Limiting Physician Freedom to Prescribe a Drug for Any Purpose: The Need for FDA Regulation, 73 Nw. U.L. REv. 801, 803 (1978) (animal and human evidence used by FDA) [hereinafter Limiting Physician Freedom].

33. See Divorcing Profit Motivation, supra note 32, at 157-59; Limiting Physician Freedom, supra note 32 , at 803.

34. See Divorcing Profit Motivation, supra note 32, at 157-61; Limiting Physician Freedom, supra note 32, at 803.

35. See Schroeder \& Shapiro, supra note 32, at 1233-36.

36. See infra notes 40-51 and accompanying text.

37. See McGarity, Substantive and Procedural Discretion in Administrative Resolution of Science Policy Questions: Regulating Carcinogens in EPA and OSHA, 67 GEO. L.J. 729, 731-49 (1979) (discussing the nature of science policy questions in relation to attempts to regulate consumer and worker exposure to chemical carcinogens). 
aninials under otherwise identical conditions. ${ }^{38}$ The aim is to determine whether the animals in the test group develop any health consequences not shared by animals in the control group. Human experimentation is conducted on the same basis. ${ }^{39}$

Assessing the results of the experiment-"data determination"-is normally a purely factual matter, and although the agency must ascertain the absence of scientific fraud, ${ }^{40}$ the process does not normally involve any scientific judgment. Even data determination, however, can occasionally involve scientific judgment. Pathologists, for example, inay interpret tissue samples of animal tumors differently; one pathologist may consider a particular tumor to be malignant, while another may reach the contrary conclusion. ${ }^{41}$

To interpret the results, an agency assesses the statistical and biological significance of the results. An event is statistically significant when it is probable that it was not the result of chance. ${ }^{42}$ An event is biologically significant when the scientific evidence suggests a causal relationship between the administration of the chemical and the different health result in the test group..$^{43}$

Both assessinents involve elements of judgment. Some statistical determinations are purely factual, but others involve both scientific and regulatory judgments. For example, there inust be a regulatory judgment as to what events are statistically significant. ${ }^{44}$ Biological significance involves scientific judgment because the evaluation of a specific study requires scientific training and experience. ${ }^{45}$

38. See Chemical Carcinogens; A Review of the Science and Its Associated Principles, 50 Fed. Reg. 10,372, 10,412 (1985) [hereinafter Chemical Carcinogens]; Cooper, Saccharin-Of Risk and Democracy, 40 Food Drug Cosm. L.J. 34, 51 (1985).

39. See Cooper, supra note 38 , at 51 .

40. See Divorcing Profit Motivation, supra note 32, at 165-68.

41. See McGarity, supra note 37 , at 740 .

42. See Cyclamate (Cylamic Acid, Calcium Cyclamate, and Sodium Cyclamate), Commissioner's Decision, 45 Fed. Reg. 61,474, 61,478 (1980) (FDA Commissioner's decision on cyclamates) [hereinafter Cyclamate Decision].

43. Relevant factors include whether there was a dose-response relationship; the incidence of tumors (or other manifestations) in the test group; whether there are similar results in other comparable studies; the incidence of tumors (or other manifestations) in the test group as compared to the control group; whether there was an acceleration of the onset of the manifestation; and the size of the study. Id. at 61,478 .

44. See id. at $61,478-81$.

45. " 'Biological significance' . . . involves consideration of biological factors," including study methodology, dose-response relationship, comparison to other studies, and determinations of a tumor's rarity. Cyclamate Decision, supra note 42, at 61,478; see also Merrill, Federal Regulations of Cancer-Causing Chemicals, in AdMINISTRATIVe CONFERENCE OF THE UNITEd STATES, 1982 ReCOMMENDATIONS AND REPORTS 21, 69-74 (1982). All of these considerations naturally require scientific expertise. 
In "data extrapolation," an agency attempts to relate the experimental results to the probable effect of the chemical on people. If the chemical has been tested in humans, the agency considers the degree of similarity between the test conditions and the conditions under which human exposure occurs. ${ }^{46}$ If, as is often the case, the chemical has not been tested in humans, ${ }^{47}$ the agency determines how to use the results of animal experimentation to predict the consequences of human contact with the chemical. Such data extrapolation is made particularly difficult where the extent to which the experimental animals are exposed to the chemical differs from the extent to which humans are likely to be exposed, 48 and where differences between human and animal physiology may lead to different reactions to the chemical.49

Data extrapolation involves both scientific and regulatory judgments. For example, determining whether the results of an animal experiment can be apphed to humans necessarily requires scientific expertise. In contrast, determination of whether a chemical is "safe" requires an agency to interpret its statutory mission-an exercise of regulatory judgment. The FDA, for instance, must apply the requirements of the Delaney Amendment, which prohibits the use of any food additive that is carcnogenic in animals or humans. ${ }^{\text {so }}$ The agency's interpretation of the Delaney Amendment provides for several exceptions to this prohibition, and each exception raises a policy issue concerning how much risk should be accepted froin an animal carcinogen knowingly added to the food supply. ${ }^{51}$

2. Epidemiological Data. In epidemiological research, investigators compare the prevalence of a disease in a group of persons who were exposed to a chemical to the prevalence of the same disease in a similar group of nonexposed persons. The greater the comparative occurrence of the disease in the first group, the more likely it is that exposure to the

46. See Merrill, supra note 45 , at 50.

47. See Divorcing Profit Motivation, supra note 32, at 158-61; see also Cooper, supra note 38, at 50; McGarity, supra note 37, at 743.

48. The problem is that the only practical test method for animal experimentation is to admin. ister large doses of a chemical to the animals. For human safety determinations, however, the regulator must decide whether the chemical causes adverse effects at lower doses of consumption or contact. Therefore the agency must estimate the extent of human contact and whether that amount is above or below the level at which contact is safe. See Cooper, supra note 38, at 55-59; see also Chemical Carcinogens, supra note 38, at 10,414-17 (1985).

49. See, eg., Chemical Carcinogens, supra note 38, at 10,416; see also Cooper, supra note 38, at 54.

50. 21 U.S.C. $\S 348(\mathrm{c})(3)(\mathrm{A})$ (1982); see also id. $\S 376(\mathrm{~b})(5)(\mathrm{B})$ (Delaney clause for color additives); id. $\S 360(d)(1)(\mathrm{H})$ (Delaney clause for animal drugs).

51. Cooper, Stretching Delaney Till It Breaks, Regulation, Nov.-Dec. 1985, at 11. Other health and safety agencies must make similar judgments. See McGarity, supra note 37, at 743-47. 
chemical caused the disease. .52

Agencies employ the same three phases of evaluation to assess this type of data. After the test results are determined, an agency must determine whether the difference between the prevalence of the disease in the test and control groups is statistically significant, and whether the study's methodology is reliable. ${ }^{53}$ Finally, it is often necessary to extrapolate the data. Because of the costs of acquiring health data about persons in a test group, epidemiologists limit the number of persons studied. ${ }^{54}$ An agency inust therefore assess how the limited size of a study affects its validityss and whether the results of the study are valid for persons exposed to the chemical under different circumstances. ${ }^{56}$

\section{The Nature of Hearing Procedures.}

As hearing procedures have changed in the last few years, particularly at health and safety agencies, agencies have becoine increasingly dependent on "hybrid rulemaking." 57 The FDA introduced another significant change in its use of the PBOI in place of an adversarial hearing. Both changes reflect the fact that soine questions of data interpretation and extrapolation are regulatory judgments, while others require scientific judgments. 58

Under the Adıninistrative Procedure Act, agencies generally utilize either adjudication-analogous to a bench trial, coinplete with an independent judge (an ALJ) and an oral presentation of evidence subject to cross-examination ${ }^{59}$ - or informal rulemaking - which involves only an informal hearing process. ${ }^{60}$ The APA's dichotony reflects Professor Kenneth Culp Davis's division of facts into two categories: "adjudicative facts" and "legislative facts." In Davis's categorization, adjudicative facts answer "the questions of who did what, where, when, how, why, with what motives or intent"; legislative facts "are general facts which

52. Schroeder \& Shapiro, supra note 32 , at 1233.

53. See, e.g., Cyclamate Decision, supra note 42, at 61,478. The FDA requires that all studies follow its regulations, found at 21 C.F.R. $\$ 58$ (1985).

54. Schroeder \& Shapiro, supra note 32 , at 1233-36.

55. See Merrill, supra note 45, at 56-57; see also Cooper, supra note 38, at 53.

56. See Merrill, supra note 45 , at $69-71$.

57. See infra notes 70-81 and accompanying text.

58. See supra notes $36-51$ and accompanying text.

59. See 5 U.S.C. $\S \S 554-557$ (1982); see generally R. PIERCE, S. SHAPIRO \& P. VERKuIL, supra note $8, \S \S 6.4 .3-.3 d$.

60. See 5 U.S.C. $\$ 553$ (1982); see generally R. Pierce, S. ShapIRo \& P. VerkuIL, supra note 8 , at $\S \S 6.4 .6-.66$. The agency is not required to use an ALJ or to provide an opportunity for oral testimony and cross-examination. It can act through the far less formal sequence of issuing notice of its intent to act, providing an opportunity for individuals aud groups to comment in writing, and accompanying its final action with a statement of basis and purpose. 
help the tribunal decide questions of law, policy, and discretion."61

The framers of the APA envisioned that formal hearings would be reserved for matters in which disputes concerning "adjudicative facts" were prominent. ${ }^{62}$ They assumed that resolving such disputes required highly developed advocacy procedures, ${ }^{63}$ separation of functions, ${ }^{64}$ and a prohibition against ex parte contacts. ${ }^{65}$ In contrast, they chose informal rulemaking for the production of regulations because they assumed that the resolution of disputes concerning "legislative facts" did not require a highly developed advocacy process. ${ }^{66}$ Further, they considered informal rulemaking preferable for the promulgation of rules because it was more efficient and allowed all interested parties to participate. ${ }^{67}$

Since the 1960's, agencies have deemphasized the use of formal hearings and informal rulemaking. Agencies have adopted summary

61. Davis, The Requirement of a Trial-Type Hearing, 70 HaRv. L. Rev. 193, 199 (1956).

62. Dep'T of Justice, Final Report of the ATtorney General's CommitTeE on ADMinistrative Procedure 43 (1941) [hereinafter Final RePORT].

63. See 5 U.S.C. $\S \S 554-557$ (1982) (adjudication procedures); see generally K. DAVIs, ADMINISTRATIVE LAW TEXT § 5.01 (1959) (distinguishing rulemaking and adjudicatory functions); FINAL REPORT, supra note 62, at 43 . In a formal hearing, accuracy is enhanced by the structured, incremental presentation of evidence, the right to address and rebut evidence, and the relatively unlimited right to cross-examination. See Harter, Negotiating Regulations: A Cure for Malaise, 71 GEo. L.J. 1, 18-19 (1982) (discussing benefits of the adversarial procedures); see also Hamilton, Rulemaking on a Record by the Food and Drug Administration, 50 TEx. L. REv. 1132, 1155 (1972) (noting that hearing provides industry the opportunity to point out agency's erroneous factual assumptions); Kennedy, The New Vogue in Rulemaking at FDA: A Foreword, 28 Food DRug Cosm. L.J. 172, 174 (1973) (discussing arguments in favor of and opposed to trial-type rulemaking procedures); Mashaw, The Management Side of Due Process: Some Theoretical and Littgation Notes on the Assurance of Accuracy, Fairness, and Timeliness in the Adjudication of Social Welfare Claims, 59 CORNELL L. REV. 772, 776-79 (1974) (discussing limitations of trial-type hearings in ensuring fairuess and accuracy). It is also promoted by the presence of an ALJ trained in the rules of evidence and procedure. See 5 U.S.C. $\S 556(b)(3)(1982)$.

64. 5 U.S.C. $\$ 554$ (d)(2) (1982) (employee who presides at hearing must not be responsible to or subject to supervision of employee engaged in investigative or prosecutorial functions of the agency); see generally R. PIERCE, S. SHAPIRO \& P. VERKUIL, supra note 8, § 6.4.3.

65. See 5 U.S.C. $\$ 557$ (d) (1982); see generally ADMINISTRATIVE CONFERENCE of THE United States, A Guide to Federal AGency Rulemaking 161-62 (1983) (noting that ex parte communications increase the likelihood that "crucial information influencing the agency decision will not be available to the reviewing court") [hereinafter ACUS GuIDE]; DeLong, Informal Rulemaking and the Integration of Law and Policy, 65 VA. L. REv. 257, 305 (1979) (prohibition of ex parte contacts protects right of interested parties to participate and the integrity of the decision process).

66. Davis, supra note 61, at 214-18.

67. See Shapiro, The Choice of Rulemaking or Adjudication in the Development of Admittistrative Policy, 78 HARv. L. REv. 921, 930-33 (1965) (informal rulemaking procedures allow greater opportunities for both general participation and agency planning and thus better allocation of limited resources than is possible in formal adjudication); see also Hutt, Philosophy of Regulation Under the Federal Food, Drug and Cosmetic Act, 28 Food DRUG Cosm. L.J. 177, 183 (1973) (rulemaking is the "most effective and efficient means by which industry-wide regulation can be achieved"). 
judgment mechanisms to avoid formal hearings, ${ }^{68}$ and have promulgated generic rules to remove certain issues from the litigation. ${ }^{69}$ Because health and safety disputes are dominated by questions of scientific and regulatory judgment-matters that do not involve typical adjudicatory fact questions because they are incapable of objective determination ${ }^{70}$ agencies have deemphasized formal hearings in these areas as well. ${ }^{71}$ At the same time, informal rulemaking has been changed in those health and safety agencies that are required to use hybrid rulemaking procedures $^{72}$ - procedures in addition to those the APA expressly requires for informal rulemaking. The additional procedures usually require the agency to hold a hearing before promulgating a regulation, ${ }^{73}$ but do not include all procedures required in formal hearings. For example, even if the hybrid procedure requires an agency to hold a hearing, parties may not have the right to cross-examine witnesses, or if cross-examination is allowed, it may be limited to certain circumstances or purposes. ${ }^{74}$

Hybrid procedures are useful in resolving certain types of scientific disputes. Some scientific disputes require a "general scientific judgment," which assesses the role and significance of scientific evidence in the regulatory process generally. For example, general scientific judg-

68. E.g., 21 C.F.R. $\S 12.93$ (1985) (FDA's summary judgment rule); 10 C.F.R. $\$ 2.749$ (1985) (Nuclear Regulatory Commission's summary judgment rule); see McGarity, supra note 37, at 761-62 (discussing EPA's proposed summary judgment rule); see also Ames \& McCracken, Framing Regulatory Standards to Avoid Formal Adjudication: The FDA as a Case Study, 64 CALIF. L. REv. 14, 1649 (1976) (discussing FDA's use of summary judgment); McGarity, supra note 37, at 759-66 (discussing FDA and EPA summary judgment procedures).

69. See McGarity, supra note 37, at 754-59 (discussing OSHA's generic rulemaking procedures); see generally Robinson, The Making of Administrative Policy: Another Look at Rulemaking and Adjudication and Administrative Procedure Reform, 118 U. PA. L. REV. 485, 490-535 (1970) (discussing FTC, FCC, CAB, and NLRB rulemaking); Note, The Use of Generic Rulemaking to Resolve Environmental Issues in Nuclear Power Plant Licensing, 61 VA. L. ReV. 869, 879-86 (1975) (discussing the Nuclear Regulatory Commission's efficient, but ad hoc, use of generic rulemaking for licensing nuclear power plants).

70. See Hamilton, supra note 63, at 1156 (noting that an expert witness "is unlikely to be shaken by cross-examination that requires comment on other statements by the same or different expert witnesses"); Harter, supra note 63, at 19-22 (discussing disadvantages inherent in adversarial process); McGarity, supra note 37, at 732 ("'[A]gencies have been forced to resolve scientific questions ... partially on policy grounds . . . [F]ormal procedures are generally inappropriate for resolving these issues ...."); see also Note, FDA Rule-Making Hearings: A Way Out of the Peanut Butter Quagmire, 40 GEO. WASH. L. REV. 726, 731-38 (1972) (discussing disadvantages of trial-type hearings).

71. See supra notes $27-56$ and accompanying text.

72. See, e.g., 33 U.S.C. $\S 1317$ (b)(1) (1982) (Clean Water Act); 42 U.S.C. $\$ 7607(d)$ (1982) (Clean Air Act); see generally Hamilton, Procedures for the Adoption of Rules of General Applicability: The Need for Procedural Innovation in Administrative Rulemaking, 60 CAL1F. L. REv. 1276 (1972); Williams, "Hybrid Rulemaking" under the Administrative Procedure Act: A Legal and Empirical Analysis, 42 U. CHI. L. REV. 401 (1975).

73. See R. Pierce, S. Shapiro \& P. VerkuII, supra note 8, § 6.4.9.

74. See infra note 80. 
ments are necessary to determine whether animal studies can be considered generally rehable to predict health effects in humans. These matters arguably are suitable for informal rulemaking because of their "legislative" nature. ${ }^{75}$ Other disputes require "specific scientific judgment," which assesses the relevance of particular data-determining, for example, whether the methodology of a particular animal study is reliable. ${ }^{76}$ Questions of "specific scientific judgment" do not involve legislative facts, because they call for expert evaluation of particular and specific data. ${ }^{77}$ Congress has found that informal rulemaking's linited advocacy process fails to expose the evidentiary inferences that experts use in deriving specific scientific judgments. ${ }^{78}$

Despite some trend toward use of hybrid rulemaking, there is no consensus concerning what additional procedures should be used. Hybrid procedures vary considerably, for example, in the type of notice required ${ }^{79}$ and the extent of cross-examination allowed. ${ }^{80}$ The greatest lack of consensus concerns the usefulness of cross-examination for health and safety matters. ${ }^{81}$

75. See McGarity, supra note 37, at 732, 736-40.

76. See supra notes $44-45$ and accompanying text.

77. See McGarity, supra note 37 , at 741-42.

78. See Hamilton, supra note 63 , at 1155 (one justification for formal procedures is that they give objecting party an opportunity to show that agency's factual assumptions are erroneous); sec also Hagan, Remarks on the Regulatory Philosophy of FDA, 28 FOOD DRUG COSM. L.J. 195, 198-99 (1973) (scientific factual disputes are best resolved in trial-type proceedings with cross-examination). But see Hoffman, The FDA's New Forms of Public Hearing-Choosing Among the Alternatives, 32 Food DRug Cosm. L.J. 330, 333-35 (1977) (one disadvantage of the formal hearing is that the administrative law judge is at best a generalist in science); Hutt, supra note 67, at 187-88 (scientific and technical issues are not well-suited to trial-type procedures); Yellin, High Technology and the Courts: Nuclear Power and the Need for Institutional Reform, 94 HARV. L. REv. 489, 549 (1981) (adversary process does not provide "a useful framework for improving the scientific underpinnings of administrative decisions").

79. Most hybrid rulemaking schemes use the APA notice provisions, 5 U.S.C. $\$ 553$ (b) (1982), but others require an expanded form of notice. See, e.g., 42 U.S.C. $\S 7607(d)(3)$ (1982) (Clean Air Act).

80. Compare Boyer, Executive Summary of Barry B. Boyer Report. Trade Regulation Rulemaking Procedures of the Federal Trade Commission, in ADMINISTRATIVE CONFERENCE of THE UNITED STATES, RECOMMENDATIONS AND REPORTS 41, 68 (1979) (use of cross-examination in hybrid FTC rulemaking) with williams, supra note 72, at 434-35 (cross-examination used only as last resort in EPA Clean Air Act rulemaking). See Verkuil, The Emerging Concept of Administrative Procedure, 78 Colum. L. REv. 258, 308-09 (1978) (comparison of how OSHA, EPA and FTC control cross-examination).

81. Compare Hutt, Impact of Recent Court Decisions on the Future of FDA Regulations: An Impromptu Response to the Remarks of the Speakers, 28 FooD DRUG CosM. L.J. 707, 714-15 (1973) (most important consideration is not cross-examination, but full participation); Kestenbaum, Rulemaking Beyond APA: Criteria for Trial-Type Procedures and the FTC Improvement Act, 44 GEO. WASH. L. REV. 679, 702 (1976) (cross-examination should be procedure of last resort); and Williams, supra note 72, at 436-55 (paper exchanges superior to cross-examination to expose faulty assumptions and methodologies) with Anderson, An Overview of Recent Regulatory Developments- 


\section{The Nature of Scientific Participation.}

The use of the PBOI is consistent with these trends in two respects. First, use of the PBOI obviates the need for a formal evidentiary hearing. ${ }^{82}$ The inovement away from formal hearings reflects the general belief that they are too cumbersome and relatively useless for the resolution of most scientific disputes. ${ }^{83}$ Second, the PBOI is a "hybrid" proceeding that involves procedures beyond those the APA requires for informal rulemaking. ${ }^{84}$

Yet the PBOI diverges from these trends insofar as they maintain the traditional reliance on advocacy procedures to evaluate specific scientific judgments. ${ }^{85}$ The PBOI rejects that approach in favor of a "scientific seminar" in which decisions are made by scientists, instead of an ALJ, and the use of adversarial procedures is greatly himited. ${ }^{86}$ Because this aspect of the PBOI is unique, ${ }^{87}$ it is important to consider tle functions and metlods of scientific input.

1. The Rationale for Scientific Participation. The idea that scientists should be employed in resolving regulatory controversies originated with proposals for a "science court." The first such proposal, advanced by Dr. Arthur Kantrowitz, advocated the use of a body composed of scientific experts to assist agencies in resolving the scientific aspects of regulatory issues. ${ }^{88}$ Proponents argued that scientists are better qualified

The Case for Evidentiary Hearings, 31 FOOD DRUG CoSM. L.J. 159, 165 (1976) (elimination of crossexamination will have a "generally negative effect on the factual integrity of any Agency action"); Dixon, Rulemaking and the Myth of Cross-examination, 34 AD. L. REV. 389, $435-43$ (1982) (crossexamination is a necessary procedural safeguard); and Robinson, supra note 69, at 522-23 (crossexainination effectively exposes error and bias). See also Boyer, supra note 80, at 63-64 (FTC attempts to control cross-examination failed).

82. The PBOI proceeding replaces a formal evidentiary hearing. See supra notes 9-18 and accompanying text.

83. See supra notes $66-67$ and accoinpanying text.

84. Compare 5 U.S.C. $\$ 553$ (1982) (APA informal rulemaking) with 21 C.F.R. $\$ \$ 13.1-.50$ (1985) (PBOI procedures).

85. See supra notes $79-81$ and accoinpanying text.

86. See supra notes $26-37$ and accompanying text.

87. See infra notes 109-12 and accoinpanying text.

88. Kantrowitz, Proposal for an Institution for Scientific Judgment, 156 SCIENCE 763, 763-64 (1967). For other proposals, see Comparative Risk Assessment: Hearings on H.R. 4939 Before the Subcomm. on Science, Research, and Technology of the House Committee on Science and Technology, 96th Cong., 2d Sess. 279, 281 (1980) (American Industrial Health Council proposal for a science panel); B. ACKERMAN, S. ACKerman, J. SAwyer \& D. HeNDERSON, The UNCERTAin SearCh FOR ENVIRONMENTAL QUALITY 156 (1974) (proposal for a technical review board); Ramo, The Regulation of Technological Activities: A New Approach, 67 A.B.A. J. 1456, 1461-62 (1980) (proposal for a "technological FBI"); see also Kleinfeld, $A$ Court of Food and Drug Appeals, 26 FooD DRUG Cosm. L.J. 279, 283-84 (1971) (proposal for specialized federal court to hear appeals froin FDA decisions). 
than laymen to understand complex scientific evidence, to distinguish between scientific and policy or value judgments, and to explain their decisions in a credible manner. ${ }^{89}$ Opponents found the idea impractical, arguing that few regulatory controversies concerned disputes about purely scientific matters, that those that did could be handled adequately by existing procedures, and that the proposal involved adversarial procedures that eitlier were ill-suited to resolve scientific disputes or would not cure the shortcomings of existing factfinding mechanisms. ${ }^{90}$

Although interest in the "science court" proposal waned, scholars continued to explore ways to use scientific expertise. In the 1970's, Judge Harold Leventhal suggested that courts should use science-trained law clerks to assist in the decision of cases involving scientific and technological information. ${ }^{91}$ Recently, Professor Joel Yellin has proposed that a committee of scientists and other experts be available for appointment by federal appellate judges as special masters in cases involving complex scientific issues. ${ }^{92}$ Like the PBOI, the special masters would assist the ultimate decisionmaker-in this case, an appellate court-by making

89. See Kantrowitz, supra note 88, at $764 \mathrm{n} .1$ ("[T]he essential information which the political community requires from the scientific community is a considered and unbiased statement of the currently available scientific facts."); Martin, The Proposed "Science Court," 75 MrCH. L. Rev. 1058,1059 (1977) (among maim reasons for establishing organization like science court are the need for accurate information on which to base policy decisions and the need to limit scientists' exercise of power by insuring that poikcymakers can ask scientists for scientific facts rather than policy recommendations). But see Sofaer, Science Court: Unscientific and Unsound, 9 ENVTL. L. 1, 4 (1978) ("[M]any scientists fail to remain objective ... [they] may possess adequate expertise, but they are acting in the decision-making process as biased advocates, rather than as neutral technicians.").

90. See Sofaer, supra note 89, at 10-15; see also Talbott, "Science Court": A Possible Way to Obtain Scientific Certainty for Decisions Based on Scientific "Fact"?, 8 ENVTL. L. 827, 838 (1978) ("It has become quite clear in modern day science that the individual scientist, either as a researcher or in the role of a science court judge, probably is not competent to evaluate all the studies that impact a particular field of endeavor."); Weinberg, The "Science Court" Controversy: Are Our Courts and Agencies Adequate to Resolve New and Complex Scientific Issues? 33 REC. A.B. CrTY N.Y. 8, 12 (1978) (concluding that legislative and administrative decisions of scientific issues are preferable to decisions of a "court of scientific orthodoxy" attempting to render definitive judgments as to scientific truth); see also Bazelon, Coping With Technology Through the Legal Process, 62 CoRnell L. REv. 817, 827-28 (1977) (troublesome features of proposed science court include: lengthy, timeconsuming adversarial proceeding devoted solely to fact-finding may unduly emphasize importance of factual issues at expense of underlying value choices; disagreements among experts cannot always be resolved through fact-finding beeause such disagreements are often due to differing views of inferences that can be drawn from agreed-upon facts).

91. Leventhal, Environmental Decisionmaking and the Role of the Courts, 122 U. PA. L. REV. 509,550 (1974) ("What an appellate court needs ... is an aide who is not a witness so much as a kind of hybrid between a master and a scientific law clerk ... to advise a court so that it could better understand the record."); Leventhal, Remarks, 7 NAT. Resources LAw. 351, 359 (1974).

92. Yellin, Science, Technology, and Administrative Government: Institutional Designs for Environmental Decisionmaking, 92 YALE L.J. 1300, 1330 (1983) (suggesting a "science advisory body"); Yellin, supra note 78, at 555-60. 
recommendations concerning the appropriate decision. ${ }^{93}$ The PBOI serves the same function by producing an "initial decision," which is then reviewed by the FDA commissioner. ${ }^{94}$

Professor Yellin argues that the use of scientists in this manner can overconie three difficulties $\mathrm{m}$ the present administrative process. First, it ensures that decisionmakers in health and safety regulation cases will have both technological and legal sophistication.95 Yellin argues that lawyers-who are trained to protect individual rights rather than produce scientific knowledge-are particularly ill-equipped to appreciate the nuances of scientific issues. ${ }^{96}$ The use of scientists also solves a second problem. To give legitimacy to the administrative process, decisionmakers must issue clear and complete explanations, even for the technologically coinplex aspects of their decisions. Using scientists to nake recommendations furthers that goal by ensuring that issues calling for scientific judgment receive competent consideration. ${ }^{97}$ The legitinacy of decisions is also enhanced because a scientific panel can consult members of the scientific commumity, and its decision will reflect the current state of the scientific hiterature. ${ }^{98}$ Third, the adversarial systen may not work effectively when lawyers address coniplex scientific issues. Most lawyers lack the sophisticated technical knowledge necessary to understand such issues fully. The use of scientists assists the process by producing a peer-review process whereby scientists can evaluate the clains inade by other scientists. ${ }^{99}$ Finally, because a scientific panel àlready possesses an advanced level of technical expertise and thus need not be educated by the participants in the proceeding, it is likely to be more efficient than alternative decisionmaking processes.

2. Effect of Scientific Participation on the Hearing Model. What type of hearing is appropriate depends on the type of scientific imput desired. One approach is to use scientific generalists, who may not be familiar with the immediate field of inquiry but, because of their

93. Yellin, supra note 78, at 555-57. The panel of special masters would be appointed by the president and confirmed by the Seuate; as a committee of scientists, engineers, and lawyers, it would be capable of reviewing technical questions submitted by the appellate courts. It would report both its scientific findings and the potential social and legal implications of matters referred to it. $I d$.

94. See 21 C.F.R. $\S \S 12.32(f)(1), 12.120$ (1985).

95. Yellin, supra note 78 , at 497,553 . Yellin notes that regulatory questions no louger consist merely of regulatory judgments; instead, "sophisticated quantitative methods for predicting the outcomes of social decisions" are now used to "analyze and shape the scientific and technological future." Yellin, supra note 92, at 1300-02.

96. See Yellin, supra note 92, at 1312; Yellin, supra note 78, at 513-14.

97. Yellin, supra note 92 , at 1324.

98. Id. at 1326-27.

99. Id. at 1332; $c$. Yellin, supra note 78, at 491, 553-54. 
background and training, are better able than laymen or lawyers to grasp the issues of scientific judgment. Alternatively, one can employ recognized experts $m$ the particular field of inquiry; these experts bring to the process not only the relevant background and training, but also a firsthand knowledge of the controversy.

Either of these models can be varied in two ways: the type of hearing procedure employed to obtain the scientific advice and the status of the advice obtained. Table I illustrates the possibilities:

\section{Table I - Nature of Input}

\begin{tabular}{lcccc} 
& $\begin{array}{c}\text { Advisory } \\
\text { Committees }\end{array}$ & $\begin{array}{c}\text { Expert } \\
\text { Witnesses }\end{array}$ & $\begin{array}{c}\text { Appointed } \\
\text { Officials }\end{array}$ & $\begin{array}{c}\text { Hearing } \\
\text { Boards }\end{array}$ \\
\hline Agency & FDA, EPA, & FDA, NRC, & FDA, & FDA, VA, \\
ESHA, CPSC & NPA & NRC & NRC \\
\hline $\begin{array}{l}\text { General or } \\
\text { specific } \\
\text { expertise }\end{array}$ & $\begin{array}{c}\text { general or } \\
\text { specific }\end{array}$ & specific & $\begin{array}{c}\text { general or } \\
\text { specific }\end{array}$ & $\begin{array}{c}\text { general or } \\
\text { specific }\end{array}$ \\
\hline $\begin{array}{l}\text { Nature of } \\
\text { hearing } \\
\text { procedures }\end{array}$ & informal & formal & formal & $\begin{array}{c}\text { informal or } \\
\text { formal }\end{array}$ \\
\hline $\begin{array}{l}\text { Advice or } \\
\text { decision }\end{array}$ & advice & advice & decision & decision \\
\hline
\end{tabular}

The most popular method for obtaining scientific input is the use of advisory committees. For example, agencies such as FDA, ${ }^{100}$ EPA, ${ }^{101}$ OSHA, ${ }^{102}$ and $\mathrm{CPSC}^{103}$ all use standing or ad hoc advisory committees,

100. The Center for Drugs uses a system of standing advisory committees to solicit advice regarding approval of new drug applications. Members of these committees are normally physicians with experience in treating the type of disease for which the drug is intended. See infra note 122; see generally Department of Health, Education \& Welfare, Review Panel on New Drug REgulation, INTERIM REPORT: THE USE OF STANDING ADVISORY COMMITTEeS BY THE BUREAU OF DRUGS OF FDA (1977) [hereinafter USE of STANDING ADVISORY CoMmitTEes].

101. See, eg., 42 U.S.C. \$ 4365 (1983) (Environmental Research, Development, and Deinonstration Authorization Act of 1978). EPA has a standing Science Advisory Board (SAB) that meets periodically with the EPA administrator to provide advice on the scientific and technical aspects of environmental issues. The SAB is composed of "a body of independent scientists and engineers of sufficient [number] and diversity to provide a range of expertise required to assess the scientific and technical aspects of environmental issues." Ashford, The Role of Advisory Committees in Resolving Regulatory Issues Involving Science and Technology: Experience from OSHA and the EPA, in LAW AND SCIENCE IN COLLABORATION, supra note 1, at 170.

102. OSHA has a mandatory, permanent advisory committee known as the National Advisory Committee on Occupational Safety and Health to advise the Secretaries of Labor and of Health and Human Services on general issues pertaining to the administration of the OSHA act. In addition, OSHA is authorized to create ad hoc advisory committees to consider specific subjects relating to the 
usually composed of scientific generahists. ${ }^{104}$ Some agencies utilize other types of advisory committees, such as the National Research Council of the National Academy of Sciences (NAS-NRC). ${ }^{105}$ Scientists also testify as expert witnesses in formal or hybrid hearings. ${ }^{106}$ Some agencies also use scientists as decisionmakers. ${ }^{107}$ Finally, scientists are often appointed

establishment of occupational standards. Both types of committees include representatives from labor, industry, state regulators, and scientific experts. Ashford, supra note 101, at 169.

103. See, e.g., 16 C.F.R. $\$ 1018$ (1985). CPSC uses a Toxicological Advisory Board whose membership is composed of nine scientific experts, three of whom are members of the American Board of Medical Toxicology. Id. $\S \S 1018.12,1018.15$.

104. See supra notes 100-03.

The Advisory Committee Act requires agencies to follow certain procedures to hold advisory committee meetings. 5 U.S.C. app. $\$ 10$ (1982); see Perritt \& Wilkinson, Open Advisory Committees and the Political Process: The Federal Advisory Committee Act After Two Years, 63 Geo. L.J. 725, 735 (1975) (advisory committee meetings must be open unless they concern matters exempted under the Freedom of Information Act; meetings must also be announced in advance unless they concern matters of national security); Tuerkheimer, Veto By Neglect: The Federal Advisory Committee Act, 25 AM. U.L. REV. 53, 56-57 (1975) (proceedings of advisory committees must be open to public and announced in Federal Register; any member of public may file a written statement or appear before the committee; detailed minutes of the meetings must be kept). Agency regulations mipose additional procedures. For example, the FDA requires advisory committees to hear presentations from parties affected by proposed agency actions. USE OF STANDING ADVISORY COMMITTEES, supra note 100, at 94-99. FDA advisory committees are also required to issue written reports of their recommendations. Id. at 109 (citing FDA Regulations on Admimistrative Functions, Practices and Procedures $\S 2.372,41$ Fed. Reg. 52,148 (1976)). The advisory committees merely file the minutes of the meetings as formal public records rather than issuing separate reports.

105. See generally Grobstein, The Role of the National Academy of Sciences in Public Policy and Regulatory Decision Making, in LAW AND SCIENCE IN COLLABORATION, supra note 1, at 115. For example, the FDA on four occasions in the 1960's asked the NAS-NRC for advice concerning whether it should ban saccharin, an artificial sweetener, because certain studies indicated that the additive was an animal carcinogen. Based on the advice it received, the agency decided against removing saccharin from the market until additional animal research was undertaken. See id. at 130-32 (discussing FDA's examination of saccharin generally).

106. For example, in the FDA's formal hcaring process, direct testimony of witnesses is submitted in advance in writing. See 21 C.F.R. $\$ 12.87$ (b) ("evidence . . . developed to the maximnm extent through written submissions"). The actual hearing process consists of the cross-examination of expert and other witnesses. See 21 C.F.R. $\$ 12.87$ (b)(1)(ii) (oral cross-examination permitted if "it appears that alternative mcans of developing the evidence are insufficient").

107. At some agencies, politically appointed officials are chosen becanse of their general scientific backgrounds. Recent FDA commissioners have been physicians or scientists. These include Arthur Hayes, Jr., M.D.; Jere Goyan, Ph.D.; Donald Kennedy, Ph.D.; and Alexander Schmidt, M.D. Who's Who IN AMERICA 1261, 1428, 1755, 2898 (1984). Similarly, the membership of the Nuclear Regulatory Commission (NRC) often includes physicists and engineers. See D. ForD, The CulT of the Atom: The Secret Papers of the Atomic Energy Commission 213 (1982). At both agencies, these officials are responsible for making final licensing decisions as part of a formal hearing process that includes an initial decision or decisions by an ALJ or by hearing boards. At the FDA, the commissioner reviews an initial deeision by an ALJ who recommends whether a new drug or food additive should be licensed. See 21 C.F.R. $\S 12.125$ (1985). At the NRC, the Commission can review the decisions of the Atomic Safety and Licensing Appeal Board. 10 C.F.R. $\S 2.786$ (1985). 
to serve on hearing boards of various types. ${ }^{108}$

The PBOI and the other hearing procedures offered by the FDA as alternatives to a formal hearing also involve scientists, ${ }^{109}$ but they differ from the methods used by other agencies in three significant ways. The hearing is not conducted according to the APA procedures for adjudication, ${ }^{110}$ the hearing panels consist only of scientists, ${ }^{111}$ and the scientists, except for the commissioner, are not agency einployees. ${ }^{112}$

3. The Rationale for the PBOI. When the FDA designed the PBOI, the agency was aware that it was creating a procedure that differed in important ways from the other inethods by which scientific input is obtained. Its rationale for the PBOI was similar to the arguments made on behalf of a science court. Unlike the proponents of the original science court proposal, the FDA distrusted the use of advocacy procedures for scientific and regulatory disputes. The agency had a disastrous experience with formal rulemaking hearings in the 1960's. ${ }^{113}$ By comparison, it had a productive experience with its advisory coinmittee system in about the same period. ${ }^{114}$

The FDA originally justified the PBOI proposal on the ground that "in those situations where coinplex scientific and medical issues are involved, a searching scientific inquiry conducted by independent experts may well be inore appropriate to resolve the matters involved than a formal evidentiary public hearing." 115 The agency noted that "[t]here had been substantial concern expressed in recent years about the need for

108. The NRC uses either an Atomic Safety and Licensing Board or an ALJ to conduct the initial hearing concerning the licensing of nuclear power plants. See 10 C.F.R. $\$ 2.721$ (1986). One member of the board is a lawyer, and the two others are scientists or engineers who have "sueh technical or other qualifications as the Commission ... deems appropriate to the issues to be decided." See $i d$. The hearing process is formal adjudication. Id. $\$ \S 2.700-.700 a$. Decisions by an ALJ or a board are reviewed by the Atomic Safety and Lieensing Appeal Board. Id. $\$ 2.786$. Membership of the appeals board, which can include seientists or engineers, is drawn from the Atomic Safety and Licensing Appeal Panel and is chosen based on "qualifications deemed appropriate to the issues to be decided." Id. $\S 2.787$.

The Veterans Administration (VA) also uses an appeals board whose membership includes scientists. The Board of Veterans Appeals hears appeals from initial disability determinations in panels of three members, one of whom is usually a physician. F. BLoch, FEderal DisAaility LAW AND PRACTICE $\S 6.7$ (1984). Unlike the NRC, however, the VA does not require that the physieian be a specialist in the disease or injury involved in the appeal. Id.

109. See supra notes $9-11,14$ and accompanying text.

110. See supra notes 21-25 and accompanying text.

111. See supra notes $9-11,14$ and accompanying text.

112. See supra notes $14-18$ and accompanying text.

113. See infra note 119 and accompanying text.

114. See infra note 123 and accompanying text.

115. Administrative Practices and Procedures: Notice of Proposed Rulemaking, 40 Fed. Reg. 40,682, 40,699 (1975) [hereinafter Administrative Practices]. 
development of more appropriate procedures than [a] trial-type hearing for resolving difficult scientific issues."116 The agency beheved that its version of the science court responded to these concerns by combining "the features of traditional scientific inquiry with the need of the law to develop a full record on which to base the Commissioner's decision and subsequent judicial review."117

The FDA became interested in using a scientific type of inquiry in part because of its desire "to avoid inappropriate use or abuse of formal trial-type hearings." 118 The commissioner explained that the FDA's experience with formal rulemaking hearings in the 1960's had been the subject of "virtually unanimous criticism" on the ground that they were a hopelessly inefficient method of resolving questions coinunonly faced by the agency. ${ }^{119}$ The commissioner noted that the PBOI incorporated some of the reforms suggested by these critics. ${ }^{120}$

The FDA's interest in the scientific type of inquiry also grew out of its behef that advocacy procedures, even when properly used, were inappropriate for scientific disputes. The preamble to the proposed PBOI quoted Professor Gellhorn's observation that "some of this country's gravest administrative deficiencies stem from lawyer-induced overrehance on courtroom methods to cope with problems."121 The FDA believed that the "scientific seminar" model of decisionmaking that its advisory committees followed was more appropriate. ${ }^{122}$

116. Id.

117. Id.

118. Id.

119. Id. at 40,698 . In fact, the agency took over eleven years to determine what percentage of peanut content was required before a product could be labeled as "peanut butter." See Hamilton, supra note 63 , at 1143-45; Note, supra note 71, at 732 .

120. Administrative Practices, supra note 115, at 40,698-99.

121. Id. at 40,698 (quoting Gellhorn, Administrative Procedure Reform: Hardy Perennial, 48 A.B.A. J. 243, 243 (1962)).

122. Telephone interview with Peter Hutt, former FDA General Counsel (July 1, 1985) [hereinafter Hutt Interview].

Since the early 1960's, the FDA has used panels of independent scientists to advise the agency on specific scientific issues. USE OF STANDING ADVISORY COMMITTEES, supra note 100, at 7-8. The Center for Drugs and Biologics, for example, has a formal system of eighteen standing advisory committees to which it refers questions for advice concerning the safety and efficacy of new drugs. See 21 C.F.R. $\$ \S 14.100,14.171$ (1985). The Center for Devices and Radiological Health has sixteen standing advisory committees. Id. In addition, the commissioner is authorized to create "color additive advisory committees" for advice concerning the safety of color additives. Id. $\S 14.140$. Members of advisory committees, who are chosen by the commissioner from nominations by interested persons and groups, are either voting or nonvoting members. Id. $\S 14.80$. To be eligible, voting members are required to "have expertise in the subject matter with which the committee is concerned and have diverse professional education, training, and experience so that [a] committee will reflect a balanced composition of sufficient scientific expertise to handle the problems that come before it." Id. $\$ 14.80($ b)(1)(i). To be eligible, voting members must also pass the FDA's conflict-ofinterest regulations. Id. $\S 14.80(\mathrm{a})(2)$. Nonvoting members are chosen "to represent and serve as a 
The FDA hoped that the advisory committee procedure's advantages of accuracy and legitimacy ${ }^{123}$ might also inhere in the PBOI. ${ }^{124}$ It also believed that the PBOI would have three important advantages over the traditional advisory committee. First, it would mean that an FDA hicensing decision would be reviewed by an independent panel of outside experts. FDA regulations provide that a party may be entitled to a hearmg, such as a PBOI, to contest an agency decision whether to license a new drug or food additive. ${ }^{125}$ The FDA believed that the PBOI would complement its advisory committees, which perform their functions before the agency makes its hicensing decisions. ${ }^{126}$ The FDA anticipated that the accuracy and legitimacy of its decisions would thus be enhanced. ${ }^{127}$ Second, the PBOI would subject the FDA's decision to more intense scrutiny than is normally applied in advisory committee meetmgs. ${ }^{128}$ Finally, the PBOI format would encourage greater public participation than the advisory committee format allows. ${ }^{129}$ This "open" aspect of the PBOI was intended to make the agency more accountable to interested parties, to enhance the FDA's public innage, and to bolster

liaison with interested individuals and organizations," such as consumer and other interest groups. Id. § 14.84(a).

Advisory committee meetings have three stages: presentation, discussion, and deliberation. Various interest groups will present information. If a new drug is under consideration, for example, those presenting information include representatives from the pharmaceutical company that is seeking approval for the drug, from the FDA scientific staff, and occasionally from public interest organizations. USE OF STANDING ADVISORY COMMITTEes, supra note 100, at 94. The naturc of the deliberation process varies from committee to committee, but decisions are usually made by consensus. Id. at 103. In cases of disagreement, there vill be a formal vote. Id. at 103-04. FDA regulations require advisory committee decisions to be in writing, but the required report "may consist of the approved minutes of the meeting or a separate written report." 21 C.F.R. $\$ 14.174$ (1985). In either form, the report must respond "to the specific issues or questions which the Commissioner has addressed to the advisory committee" and to state "the basis of the advice and recommendations of the committee." Id.

123. A government study reported:

Experts provide valuable advice on complex technical issues and assist the agency in deciding critical questions of scientific judgment.... [A]dvisory committees [also] offer FDA a dialogue with the nation's foremost experts in drug therapy. The committees are thus an important source of peer review for proposed FDA decisions. For these reasons, use of advisory committees increases public and industry acceptance of FDA decisions and improves the credibility of the agency.

Department of Health, Education, and Welfare, Review Panel on Neiv Drug ReguLATION, FINAL REPORT 52 (1977) [hereinafter HEW FINAL REPORT].

124. See supra note 122 and accompanying text.

125. See supra notes $7-11$ and accompanying text.

126. See infra notes $322-23$ and accompanying text.

127. Interview with Katherine Copp and Fletcher Campbell, Counsel for the Center for Drugs and Biologics, Depo-Provera Hearing, in Washington, D.C. (June 27, 1985) [hereinafter Copp and Campbell Interview]; see infra notes 320-46 and accompanying text.

128. See infra notes 322-28 and accompanying text.

129. Copp and Campbell Interview, supra note 127; Interview with Jeff Stribling, Counsel for Depo-Provera PBOI, in Washington, D.C. (June 25, 1985) [hereinafter Stribling Interview]. 
the agency's reputation for respecting scientific expertise. ${ }^{130}$

The FDA hoped the PBOI had one other advantage. One function of advisory committees is to develop a consensus among scientists on difficult issues requiring scientific judgment. ${ }^{131}$ The agency hoped that the PBOI might serve this function as well. ${ }^{132}$

The FDA clearly had "high hopes" for the PBOI. The agency saw it as more efficient, more accurate, and more legitimate than a formal hearing. The PBOI would be more efficient because it would be largely nonadversarial. It would be more accurate because the board was composed of experts. Finally, it would be inore legitimate because the PBOI process was both more open and more likely to lead to a consensus on difficult scientific issues.

\section{Applications of the PBOI Procedure}

\section{A. The "Aspartame" Case.}

Aspartame, which is sold under the brand name of NutraSweet, is a popular food additive commonly used as a sugar substitute in diet soft drinks and other products. The FDA's 1981 decision to approve aspartaine ended years of controversy surrounding saccharin, another sugar substitute; aspartame has almost completely replaced saccharin in the marketplace. ${ }^{133}$ The FDA had atteinpted to ban the use of saccharin on the ground that it was an animal carcinogen, but Congress overruled the agency and instead required a label that warned consumers of that hazard. ${ }^{134}$ The agency had previously banned the sale of cyclamates on the same ground. ${ }^{135}$ As a result, there was considerable public interest in whether aspartame presented similar probleins. ${ }^{136}$

130. Copp and Campbell Interview, supra note 127; Stribling Interview, supra note 129.

131. Hutt Interview, supra note 122; cf. UsE of STANDing ADVISORY CoMmitTeES, supra note 100, at 103 (most advisory committee decisions are by "consensus").

132. Hutt Interview, supra note 122.

133. See, e.g., Searle Sweetener Expands Its Market, N.Y. Times, Sept. 20, 1983, at D4, col. 5 (six major soft-drink makers decide to use aspartame in diet soft drinks); Aspartame Builds a Market, N.Y. Times, Sept. 3, 1983, at 29, col. 3 (describing market displacement of saccharin by aspartame); Searle's Push into Sweeteners, N.Y. Times, Oct. 24, 1982, § 3, at 4, col. 3 (describing the commercial introduction of aspartame).

134. See Cooper, supra note 38 , at 43-65.

135. Food Additives: Exemption of Certain Food Additives from the Requirement of Tolerances, 34 Fed. Reg. 17,063, 17,063 (1969); see also New Drugs: Procedural and Interpretive Regulations, 35 Fed. Reg. 13,644, 13,644-45 (1970).

136. This public interest was heightened by two events. One was the discovery that the Searle Company, which owned the patent on aspartame, had hired an animal research firm that had previously submitted fraudulent data to the FDA for other companies. The other was that a prominent public interest advocate, James Turner, had challenged the FDA's announcement that it intended to approve aspartame. 
1. Pre-Hearing Process. In March 1973, G. D. Searle \& Co. petitioned the FDA to approve the use of aspartame in foods. ${ }^{137}$ After the FDA issued the requested regulation in July $1974,{ }^{138}$ two requests for a hearing were received. ${ }^{139}$ At that time, the agency stayed its regulation approving the use of aspartame. ${ }^{140}$

The two parties questioning aspartame's safety were Dr. John O1ney, a professor of psychiatry at Washington University School of Medicine, in St. Louis, and James S. Turner, a lawyer who represented himself and a consumer group called Legal Action for Buyer's Education and Labeling (LABEL). Both waived their right to a formal evidentiary hearing and requested that the FDA convene a Public Board of Inquiry. ${ }^{141}$ The FDA granted that request, ${ }^{142}$ and also granted the requests of six interested persons to inake oral presentations as nonparty participants. ${ }^{143}$ The PBOI hired two consultants. ${ }^{144}$

The FDA postponed convening the board until it could resolve the question whether certain of Searle's animal data were unreliable. ${ }^{145}$ Universities Associated for Research and Education in Pathology (UAREP) had reviewed the data in question. ${ }^{146}$ The FDA received the UAREP report on Deceinber 13,1978, and agreed with its conclusion that the Searle data were authentic. ${ }^{147}$

In preparation for the PBOI, the FDA negotiated with Olney and Turner concerning the scope of the issues to be decided by the board. The following questions were submitted to the board: (1) whether the ingestion of aspartame, alone or in conjunction with glutamate, poses a risk in humans of mental retardation or other brain-related injuries;

137. G.D. Searle \& Co.: Notice of Filing of Petition for Food Additive, 38 Fed. Reg. 5921, 5921 (1973).

138. Food Additives: Food Additives Permitted in Food for Human Consumption, 39 Fed. Reg. 27,317, 27,319 (1974); see also Food Additives: Aspartame; Correction, 39 Fed. Reg. 34,520, 34,520 (1974) (codified at 21 C.F.R. § 172.804 (1974)).

139. See Aspartame; Stay of Effectiveness of Food Additive Regulation, 40 Fed. Reg. 56,907 (1975); Aspartame; Commissioner's Final Decision, 46 Fed. Reg. 38,283, 38,285 (1981) [hereinafter Commissioner's Final Decision].

140. Aspartame; Stay of Effectiveness of Food Additive Regulation, 40 Fed. Reg. 56,907 (1975).

141. Id.

142. Aspartame; Ruling on Objections and Notice of Hearing Before a Public Board of Inquiry, 44 Fed. Reg. 31,716 (1979).

143. 45 Fed. Reg. 2908 (1980). The six presenters were: the Bureau of Foods, FDA; John W. Olney, M.D.; James S. Turner; G.D. Searle \& Co.; Lloyd J. Filer, Jr., M.D.; and Richard J. Wurtman, M.D. Id.

144. The consultants were William Nyhan, M.D., and Milton Brightman, M.D., 46 Fed. Reg. $38,286 \&$ n.2 (1981).

145. 44 Fed. Reg. 31,717 (1979).

146. Id.

147. Id. 
(2) whether the mgestion of aspartame may induce brain tumors in rats; and (3) whether, in light of the answers to these questions, the FDA should allow the use of aspartame in foods. 148

Olney, Searle, and the FDA's Center for Food Additives all submitted nominees for the PBOI; ${ }^{149}$ the FDA chose Dr. Walle Hauta of the Department of Psychology, Massachusetts Institute of Technology, as chairman; Dr. Peter J. Lainpert of the Department of Pathology, University of California at San Diego; and Dr. Vernon Young of the Department of Nutrition and Food Science, Massachusetts Institute of Technology. ${ }^{150}$

2. Hearing Process. The January 1980 PBOI hearing lasted three days and consisted of three sets of presentations by Olney, the Bureau of Foods, and Searle. ${ }^{151}$ Each set of presentations addressed one of the three questions given to the board by the commissioner and followed a format similar to that of scientific meetings, allowing for the use of illustrative shides ${ }^{152}$ and for interruptions and questions from board members. ${ }^{153}$ The other persons present were not allowed to interrupt the presentations. ${ }^{154}$

Following the presentations, the parties, nonparty participants, and the board's consultants were allowed to make comments or to question witnesses or other participants in the hearing. ${ }^{155}$ Several times during these question periods the proceeding resembled a roundtable discussion. These interchanges were almost always nonconfrontational and nonadversarial im nature. ${ }^{156}$ Lawyers did not participate in the hearing in any capacity, except for occasional comments by Turner, who was one of the parties. ${ }^{157}$

148. See Commissioner's Final Decision, supra note 139 , at 38,286 .

149. $I d$.

150. $I d$.

151. See Commissioner's Final Decision, supra note 139, at 38,286. For examples of these presentations, see [In the matter of] Aspartame, No. 75-F-0355, Hearing Record at 5 (Dec. 30, 1980) (presentation of Neil Singletary, M.D., Bureau of Foods) [hereinafter Aspartame Record]; id. at 25 (presentation of John Olney, M.D.); id. at 86 (presentation of Louis Stegink, M.D., Searle consultant).

152. See, e.g., Aspartame Record, supra note 151, at 87 (presentation of Louis Stegink, M.D., Searle consultant).

153. See, e.g., Aspartame Record, supra note 151, at 130-33 (questions by Board members during presentation of Louis Stegink, M.D., Searle consultant).

154. See supra notes $21-23$ and aecompanying text.

155. See, e.g., Aspartame Record, supra note 151, at 197 (comments of Richard Wurtman, M.D., nonparty participant).

156. Interview with Robert Becker and Peter Safir, Counsel for Searle, Aspartame Hearing, in Washington, D.C. (June 24, 1985) [hereinafter Becker and Safir Interview].

157. See, e.g., Aspartame Record, supra note 151, at 234-36. 
3. Post-Hearing Process. On October 1, 1980, the board recommended that the FDA revoke its approval of aspartame until additional safety testimg could be performed. ${ }^{158}$ Although the board concluded that aspartame did not pose a risk of mental retardation or other brain injury, it also determined that there was insufficient evidence to determine whether aspartame induced tumors in rats. ${ }^{159}$ On July 24, 1981, the FDA commissioner issued his final decision, which favored the approval of aspartame. ${ }^{160}$ Consequently, the FDA reinstated the aspartame regulation. ${ }^{161}$

The commissioner affirmed the board's finding that aspartame did not pose a risk of brain injuries. ${ }^{162}$ The question had arisen because aspartame is composed of two amino acids, phenylalanine (PHE) and aspartic acid (ASP), both of which-previous studies had shown-could be dangerous. ${ }^{163}$ Prolonged concentrations of PHE in a person's blood plasma can cause brain damage, ${ }^{164}$ and a one-time concentration (or surge) of ASP can cause nerve cell damage (focal brain lesions) and neuroendocrime dysfunctions. ${ }^{165}$ To resolve whether aspartame could have these effects, the PBOI engaged in a two-part inquiry. First, the board evaluated published studies to determine the toxic threshold ${ }^{166}$ for PHE and ASP. Then the board determined whether, based on other studies, the use of aspartame would cause individuals to consume more than the toxic threshold amount of PHE or ASP. ${ }^{167}$ The board and the commissioner both concluded that the use of aspartame posed no risk that $\mathrm{PHE}^{168}$ or $\mathrm{ASP}^{169}$ would be absorbed above their toxic thresholds.

158. Commissioner's Final Decision, supra note 139, at 38,286.

159. In the Matter of Aspartame, Initial Decision of Public Board of Inquiry 49 (1980) [hereinafter Aspartame PBOI Decision]; see also [In the matter of] Aspartame, [Transfer Binder, Develop. ments 1980-81] FooD DRUG COSM. L. REP. (CCH) ๆ 38,072, at 38,349 (1980) (excerpted version of PBOI decision).

160. Commissioner's Final Decision, supra note 139, at 38,285.

161. Food Additives Permitted for Direct Addition to Food for Human Consumption; Reinstatement of Regulation for Aspartame, 46 Fed. Reg. 50,947, 50,948 (1981).

162. Commissioner's Final Decision, supra note 139, at 38,285.

163. See Aspartame PBOI Decision, supra note 159, at 10; see also Commissioner's Final Decision, supra note 139 , at 38,287-94.

164. See Aspartame PBOI Decision, supra note 159, at 10; see also Commissioner's Final Decision, supra note 139 , at 38,290 .

165. See Aspartame PBOI Decision, supra note 159, at 22; see also Commissioner's Final Decision, supra note 139 , at 38,291 .

166. The toxic threshold is the highest dosage at which no adverse effects are observed. See Aspartame PBOI Decision, supra note 159, at 11.

167. Id.

168. For PHE, the board evaluated studies in which normal adults, pregnant women, one-yearold children, and PKU children consumed large amounts of aspartame. PKU (phenylketonuria) is an inherited disorder in which the body cannot rid itself of PHE. The accumulated PHE can cause severe mental retardation. Aspartame PBOI Decision, supra note 159, at 11-12. The board ex- 
The board ${ }^{170}$ and the commissioner ${ }^{171}$ both rejected arguments that PHE was dangerous to certain children and fetuses on the regulatory, or policy, ground that aspartame posed no greater risk of harm to these persons than the consumption of protein found in many products already on the market. ${ }^{172}$ Both also rejected arguments that the board had incorrectly evaluated the evidence concerning ASP by disregarding relevant studies and overeinphasizing irrelevant studies. ${ }^{173}$

The coinmissioner and the board disagreed, however, on the correctness of the board's interpretation of the rat studies conducted by Searle. ${ }^{174}$ This issue had arisen because some test animals fed aspartame had developed brain tumors. ${ }^{175}$ The FDA had asked the board to decide whether these experiments had "biological significance"-whether a causal relationship existed between the developinent of the tumors and consumption of aspartame by the test animals. ${ }^{176}$ The board found that one of the three available studies imphied a causal relationship; problems with the other studies prevented any firm conclusions. ${ }^{177}$ The commis-

amined how the ingestion of aspartame affected the PHE levels in these test subjects. Based on the resuits, the board concluded that individuals could not consume enough aspartame to raise their PHE levels to the toxic threshold. Id. at 13-21.

169. For ASP, the board established a toxic threshold by using data from the most sensitive species tested and from the most sensitive age group of that species. Id. at 23-26, 36. This choice was made because nerve cell damage can occur from only one surge of toxic ASP concentrations. Id. at 36. Based on previous studies concerning consumption of glutamic acid (GLU), which is metabolized in the same way as ASP, the board concluded that the biological mechanisms that protect humans from GLU and ASP surges would not be overcome by the use of aspartame. The board noted that this conclusion was correct even though it chose a low toxic threshold. Id. at 38 . The commissioner affirmed these conclusions with minor exceptions. Commissioner's Final Decision, supra note 139 , at 38,292, 38,294.

170. Aspartame PBOI Decision, supra note 159, at 20-22.

171. Commissioner's Final Decision, supra note 139, at 38,291 .

172. See Letter from John W. Olney, M.D., to FDA Commissioner Goyan, at 1 (Dec. 19, 1980) (exceptions to PBOI decision on aspartame) [hereinafter Olney Exceptions]. For a description of the dangers of PHE, see supra note 168.

173. These arguments were made by Dr. Olney. Commissioner's Final Decision, supra note 139 , at 38,293 (suggesting that Olney exccptions presented a "one-sided" view of the data and emphasizing the safety found to be associated with the use of aspartame in human studies); see also Olney Exceptions, supra note 172, at 2-6 ("[E]vidence presented at the PBOI . . . must be considered 'deficient' in the sense that none of the studies was designed to answer the specific question whether blood Glu/Asp levels do or do not rise above the toxic threshold in immature humans following ingestion of $\mathrm{Glu}+$ Asm.").

174. Commissioner's Final Decision, supra note 139 , at 38,300 .

175. Aspartame PBOI Decision, supra note 159, at 40 .

176. See supra notes $42-43$ and accompanying text.

177. Aspartame PBOI Decision, supra note 159, at 45-47. The board found one study troubling because it indicated a high rate of death in young test rats and a possible dose-effect relationship. Id. at 47. The board found a second study "puzzling" because it used an insufficient number of experimental animals and "bizarre" because the control group had a higher incidence of brain tumors than the board thought was normal. Id.; see infra notes 181-82 and accompanying text. 
sioner determined that the board had based its conclusion on evidence marred by calculation ${ }^{178}$ and evaluation errors. ${ }^{179}$ As a result, the commissioner concluded that the test group of rats did not have a statistically significant higher incidence of tumors than those in the control group. ${ }^{180}$

The significant difference between the commissioner and the board on this issue concerned a matter of scientific judgment. The board concluded that one animal study was invalid because the incidence of tumors in the control group of rats was higher than normal for spontaneous tumors in that type of animal. ${ }^{181}$ The commissioner disagreed. He found that the incidence of tumors in the control group was consistent with the incidence rate of spontaneous tumors indicated by the literature. ${ }^{182}$

The commissioner also overruled the board on the third issue: whether aspartame should be hicensed. The board had taken the position that, because there was evidence indicating that aspartame might cause brain tumors, the safety of the product could not be determined without additional testing. ${ }^{183}$ The conmissioner, however, concluded that the product could be marketed because the Searle data did not suggest that aspartame caused brain tumors. ${ }^{184}$ The commissioner also refused to call a new hearing concerning a fourth issue raised on appeal: whether or not the Searle data were authentic. ${ }^{185}$

One year later, Searle petitioned the FDA to amend the food additive regulation to permit the use of aspartame in carbonated beverages. ${ }^{186}$

178. The commissioner held that the board's finding of a causal relationship in one study was erroneous because the Board had made a factual error in calculating the age at which some young rats had died. Commissioner's Final Decision, supra note 139, at 38,300. He also found that the Board had made a statistical error in calculating a possible dose-response relationship by improperly adding the results of two studies. Id. at 38,299 .

179. The commissioner rejected the board's conclusion that one study was unreliable, because he found Searle had used a sufficient number of test animals, id. at 38,300, and because the board was mistaken concerning the normal incidence of tumors for a control group. See infra notes 181-82 and accoinpanying text.

180. Commissioner's Final Decision, supra note 139 , at 38,301 .

181. Aspartame PBOI Decision, supra note 159, at 42-47; see also Commissioner's Final Decision, supra note 139 , at 38,295 .

182. Commissioner's Final Decision, supra note 139, at 38,295.

183. Aspartame PBOI Decision, supra note 159 , at 49.

184. Coinmissioner's Final Decision, supra note 139, at 38,303.

185. Before the PBOI was convened, FDA investigated the possibility that the Searle data might be fraudulent, but the agency pronounced the data valid after the results were independently verified. See supra note 147 and accompanying text. James Turner argued that the board had to determine the authenticity of the studies because that issue was directly relevant to any determination of safety. See Exceptions for Turner at 1-3, [In the matter of] Aspartame, No. 75-F-0355 (Dec. 17, 1980) [hereinafter Turner Exceptions]. The commissioner affirmed the PBOI's determination that the issue was outside the scope of the hearing because it was not one of the charges he originally made to the PBOI. Commissioner's Final Decision, supra note 139, at 38,301.

186. 47 Fed. Reg. 46,140 (1982). 
FDA amended the regulation as requested. 187 Although objections were filed by several parties, ${ }^{188}$ the FDA initially denied their request for a stay ${ }^{189}$ and ultinately denied their request for a hearing. ${ }^{190}$

The FDA's decision to hicense aspartame for use in carbonated beverages was affirmed in Community Nutrition Institute v. Novitch.191 Based on the tests and studies evaluated by the agency, the court deternined that the FDA's decision was justified. ${ }^{192}$ The court concluded, therefore, that those who objected to the use of aspartame in beverages had not raised any material issue that required the FDA to hold further hearings. ${ }^{193}$

\section{B. The "Depo-Provera" Case.}

Depo-provera is approved for use in over ninety countries as an injectable contraceptive. It has been licensed in almost all countries where approval has been sought, the niajor exception being the United States. ${ }^{194}$ The Upjohn Conipany ("Upjohn") has sought regulatory approval in the Uinted States for over twenty-five years. ${ }^{195}$ The PBOI convened by the FDA to consider approval of depo-provera recommended against hicensing the drug. To date, the commissioner has not acted on this recomniendation. By conparison, a panel of scientific experts in Great Britain recomnended that the drug be approved, and in 1984 the British hicensing authority agreed.196

The FDA's actions concerning depo-provera generated considerable public interest. ${ }^{197}$ Forty-four nidividuals and organizations participated in the PBOI proceeding, including representatives from the National Cancer Institute, the National World Health Network, the World Health Organization, and the Agency for International Developinent. ${ }^{198}$

187. 48 Fed. Reg. 31,376 (1983).

188. See id.

189. 48 Fed. Reg. 42,899 (1983).

190. 49 Fed. Reg. 6672,6681 (1984). This reference also contains a complete publication of FDA's final rule concerning Aspartame. Id. at 6672.

191. 773 F.2d 1356, 1367 (D.C. Cir. 1985).

192. Id. at 1363 .

193. Id. at 1367 .

194. Richard \& Lasagna, Depo-Provera: Comparison of the U.K. and U.S. Advisory Board Recommendations 3 (Aug. 20, 1985) (unpublished manuscript on file with author).

195. See infra notes 199-213 and accompanying text.

196. Richard \& Lasagna, supra note 194, at 6.

197. See Rosenfield, Maine, Rochat, Shelton \& Hatcher, The Food and Drug Administration and Medroxyprogesterone Acetate: What Are the Issues?, 249 J. AM. MED. A. 2922, 2923 (1983) (chronicling FDA actions and discussing pertinent scientific literature).

198. See infra notes 208-09 and accompanying text. 
1. Pre-Hearing Process. In 1960, the FDA approved depoprovera ${ }^{199}$ for the treatment of two problems associated with pregnancy. ${ }^{200}$ In 1963, Upjohn petitioned the FDA for permission to begin clinical studies to determine depo-provera's safety and efficacy as a contraceptive. ${ }^{201}$ In 1967, Upjolin submitted data from experiments in which depo-provera was used as a contraceptive through intramuscular injection in humans. ${ }^{202}$ Seven years later, the FDA permitted Upjohn to market the drug as a contraceptive. ${ }^{203}$

In October 1974, less than two months after approving the drug, the FDA stayed its approval, ${ }^{204}$ an action prompted by Congress's concern that depo-provera might increase the risk of cervical cancer. ${ }^{205}$ In 1978, the agency withdrew its approval based on evidence indicating that depoprovera caused maminary tumors in beagles. ${ }^{206}$ In the same year, Upjohn waived its right to a formal evidentiary hearing, and the FDA granted its request for a PBOI. ${ }^{207}$ When the FDA invited interested persons to submit notices of participation, ${ }^{208}$ forty-four persons responded and made presentations to the board.209

In 1981, after the required nomination process, the FDA named the members of the PBOI: Dr. Judith Weisz of the Department of Obstetrics and Gynecology, Pennsylvania State University Medical Center; Dr. Paul Stolley of the Department of Research Medicine, University of Pennsylvania; and Dr. Griff Ross, Associate Dean for Clinical Affairs,

199. Depot medroxyprogesterone acetate or DMPA. See Rosenfield, Maine, Rochat, Shelton \& Hatcher, supra note 197, at 2922.

200. The health problems were endometriosis, which is the presence of endometrial tissue outside the uterus, and habitual, or threatened, spontaneous abortions. Weisz, Ross \& Stolley, Report of the Public Board of Inquiry on Depo-Provera 8 (Oct. 17, 1984) (unpublished report on file with author) [hereinafter PBOI Report]; see [New Matters] FoOD DRUG CoSM. L. REP. (CCH) \| 38,291, at 39,635-36 (Dec. 3, 1984) (excerpts of PBOI Report).

201. See 38 Fed. Reg. 27,940, 27,940 (1973).

202. 43 Fed. Reg. $28,555,28,555-56$ (1978).

203. 39 Fed. Reg. 32,907, 32,910 (1974). Prior to this action, however, FDA withdrew its approval of depo-provera for use in pregnancy-related problems beeause there was insufficient evidence that it was effective for those purposes. 38 Fed. Reg. 27,940 (1973).

204. 39 Fed. Reg. 38,227 (1974).

205. Use of Advisory Committees by the Food and Drug Administration: Hearings Before the Subcomm. on Intergovernmental Relations, 93d Cong., 2nd Sess. 323-41, 353-90 (1974) (statements of Rep. Fountain).

206. 43 Fed. Reg. 28,556 (1978).

207. 44 Fed. Reg. 44,275 (1979).

208. Id. at 44,274 .

209. Participants included representatives from the Centers for Disease Control, the National Cancer Institute, the National World Health Network, the World Health Organization, the Agency for International Development, and a host of American medical schools. See Transcript of DepoProvera PBOI Hearing (No. 75N-0124), at 2-2a (Jan. 10, 1983), 2-2a (Jan. 11, 1983), 2-3 (Jan. 12, 1983), 2-2a (Jan. 13, 1983), and 1-1a (Jan. 14, 1983) [hereinafter Depo-Provera Transcript]. 
The University of Texas Medical School, Houston. ${ }^{210}$ The hearing, however, was not convened until January 1983.211 In the intervening period, there was a pre-hearing conference ${ }^{212}$ and an opportunity for participants to submit data that post-dated the FDA's 1978 decision to withdraw approval. 213

2. Hearing Process. The depo-provera hearing, which lasted five days, ${ }^{214}$ was followed by a second, one-day hearing ${ }^{215}$ to receive a special report from six consultants. ${ }^{216}$ The initial hearing consisted of presentations by Upjohn, by the FDA's National Center for Drugs and Biologics (now the Center for Drugs and Biologics), and by many nonparty participants. ${ }^{217}$ Upjohn and the Center for Drugs and Biologics were each given one day for their presentations. ${ }^{218}$ Three days were allocated for presentations by nonparty participants. ${ }^{219}$ Unlike the aspartame hearing, where witnesses appeared several times and discussed issues one at a time, ${ }^{220}$ each presentor was free to cover any of the issues that were before the PBOI.

The board members often asked witnesses specific questions concerning a particular matter or piece of evidence. ${ }^{221}$ Questions by the parties and participants were handled differently as the hearing progressed. On the first day, the board asked the questions they received at the end of the day, when Upjohn had completed its presentations. For the remainder of the hearing, the board asked the participants' questions at the end of each presentation.222 During the first two days, the board attempted to ask all of the questions submitted by the participants. At the start of the third day, the board announced that the previous policy had become

210. Id. at 2 (Jan. 10, 1983).

211. 47 Fed. Reg. 55,518 (1982).

212. 47 Fed. Reg. 36,470 (1982).

213. 47 Fed. Reg. 346 (1982).

214. PBOI Report, supra note 200 , at 4,15 .

215. 48 Fed. Reg. 31,910 (1983).

216. The panel consisted of " 6 consulting pathologists who reviewed the histopathology slides from the monkey study to determine the nature and origin of the malignant tumors in 2 of 12 survivor monkeys in the high-dose Depo-Provera group." PBOI Report, supra note 200, at 15 . The PBOI regulations provide for a second hearing to resolve a particular scientific issue. See supra note 24 and accompanying text.

217. PBOI Report, supra note 200, at 4.

218. Depo-Provera Transcript, supra note 209, at 2-3 (Jan. 10, 1983); id. at 2-3 (Jan. 11, 1983).

219. Id. at 2-3 (Jan. 12, 1983); id. at 2-3 (Jan. 13, 1983); id. at 1-2 (Jan. 14, 1983).

220. See supra notes 151-52 and accompanying text.

221. See, e.g., Depo-Provera Transcript, supra note 209, at 225-45 (Jan. 11, 1983) (board members inquired into the experimental methods used in examining the effect of depo-provera on female reproductive system); id. at 11-25 (Jan. 14, 1983) (board inquired into the reliability of a study of depo-provera's carcinogenicity); see also Stribling Interview, supra note 130.

222. Depo-Provera Transcript, supra note 209, at 4-5 (Jan. 11, 1983). 
unwieldy. It decided, therefore, to raise only those questions that "will be helpful in obtaining the kind of information that we need to make our decision."223

The tenor of the proceeding reseinbled a legislative hearing rather than the scientific-seminar atmosphere of the aspartame proceeding. In the aspartame hearing, there was often a direct exchange or debate among the board, the participants, and the consultants. ${ }^{224}$ In the depoprovera hearing, non-board inembers did not participate directly; their questions were funneled through the board members. ${ }^{225}$

This hearing, however, was also conducted in a nonconfrontational and nonadversarial manner. Although the questioning was often sharp, it was more congenial than a cross-examination. ${ }^{226}$ Further, there was almost no direct participation by lawyers in this proceeding, except when the legal counsel for some participants offered a closing summary of the evidence. 227

3. Post-Hearing Process. In October 1984, the PBOI submitted its decision. ${ }^{228}$ The PBOI recommended that depo-provera should not be approved for use as a huinan contraceptive because of inadequate information regarding the drug's safety. ${ }^{229}$ The coinmissioner has not issued a final report.

The commissioner had charged the board to resolve seven questions, including "[w]hether, in comparison with other drugs approved for contraception, the benefits of Depo-Provera . . . outweigh its risks under conditions of general marketing." 230 The other questions addressed whether the drug had carcinogemic or teratogemic potential, ${ }^{231}$ whether there were other probleins associated with the drug, ${ }^{232}$ and whether the

223. Id. at 4 (Jan. 12, 1983).

224. See supra notes 151-57 and accompanying text.

225. See supra notes $221-23$ and accompanying text.

226. See supra note 221.

227. Interview with Solomon Sobel, M.D., Director of the FDA Division of Metabolisin \& Endocrine Drug Products, in Washington, D.C. (June 26, 1985) [hereinafter Sobel Interview].

228. 49 Fed. Reg. 43,507 (1984).

229. PBOI Report, supra note 200 , at 179.

230. Id. at 2 .

231. The commissioner asked the board whether "data from beagle dog and monkey studies submitted by Upjohn indicate a potential risk of breast or endometrial cancer in humans from DepoProvera"; whether "the human data submitted by-Upjohn can, as Upjohn claims, successfully refute the risk of human cancer suggested by the animal data"; and whether, "in the event of contraceptive failure, use of Depo-Provera may increase the risk of teratogenic effects to a greater extent than would other systemic contraceptives." Id. at 2 (emphasis in original).

232. The coinmissioner asked the board whether, "in view of Depo-Provera's adverse side effects or pharmacologic effect, estrogen therapy is likely to be prescribed in addition to Depo-Provera in a significant nnmber of patients," and whether "an approval of Depo-Provera for contraception under 


\section{drug might be safe and effective for only some types of patients. ${ }^{233}$}

The board's recommendation that depo-provera not be approved was based principally on its concern about the drug's carcinogenic effects. ${ }^{234}$ Dogs and monkeys who were administered depo-provera developed inalignant tumors. The board concluded that Upjohn's animal studies indicated the drug might have been the cause of the tumors, ${ }^{235}$ and rejected Upjohn's contention that, because of the physiological differences between experimental animals and humans, the animal studies were not relevant evidence of the carcimogenic risk in humans. ${ }^{236}$ The board also rejected the contention that Upjohn's clinical data successfully rebutted the inferences from the animal data that depo-provera might be carcinogenic. Although there were many published studies concerning the use of depo-provera in other countries, the board concluded that this evidence was inconclusive because of methodological probleins. ${ }^{237}$

general marketing conditions is likely to increase use of the drug as a contraceptive under conditions not stipulated in the approved labeling or is it [sic] likely to increase use of the drug for unrelated indications." Id. (empliasis in original). On its own initiative, the board investigated whether the drug would affect bone and plasma lipoproteins. Id. at 7.

233. The commissioner asked the board whether "there are conditions of labeling and distribution controls which would permit marketing of Depo-Provera as a safe and effective drug on a limited basis (i.e., Whether there may be certain patients in the U.S. for whom benefits of Depo-Provera for contraception outweigh the risks)." Id. at 2-3 (emphasis in original).

234. Id. at 173-75. The other issues either were decided in a way that favored Upjohn or were not reaclied in liglit of the board's disposition of the cancer issue. The PBOI decided that there was no evidence to suggest that depo-provera posed greater risks to fetuses than other approved contraceptives, id. at 115-16; it was unlikely that estrogen therapy would be used in conjunction with the drug because it would be ineffective for that purpose, $i d$. at 145; no decision was necessary concerning possible unapproved uses given the board's recommendation not to approve the drug, id. at 166; and the drug should not be licensed for any limited group of women because risk-benefit decisions could be made appropriately only on a case-by-case basis. Id. at 169 . One member of the board would have approved depo-provera for two groups of woinen: the mentally retarded and drug addicts. Id. at 170 .

235. Id. at $24,30-31,68-69$. The strongest evidence was the fact that the beagle study indicated a dose-response relationship: the frequency and timing of the tumors in the test group of animals varied in relationship to the amount of the drug administered. Id. at 30. See supra notes 38-41 and accompanying text (description of criteria used to evaluate animal studies).

236. See Exceptions To Report of Public Board of Inquiry and Brief for the Upjolin Company at 41-47, [In the Matter of] Depo-Provera Sterile Aqueous Suspension for Contraception, 78N-0124 (Jan. 24, 1985) [hereinafter Upjoln Exceptions]. Although some plyysiological differences are generally recognized, the board rejected Upjohn's argument on the ground that Upjohn's claims were speculative and unsubstantiated. PBOI Report, supra note 200, at 54, 64.

237. PBOI Report, supra note 200 , at $80-81$. The board's principal objections were that there were too few women in each study and no long-term systematic studies had been conducted. Id. at 87-88. Other problems were inadequate or inappropriate control groups, failure to control or adjust for other causes of risk, lack of documentation, and lack of information on whether women in the United States were comparable to women in the studies. $I d$. at 85-88. 
The board based its conclusions about the carcinogenic potential of depo-provera on an evaluation of the rehability of the available aninal and clinical data. ${ }^{238}$ The differences between the board and Upjohn concerned whether it was legitimate to extrapolate the animal data ${ }^{239}$ and whether the clinical studies, which did not indicate that the drug caused cancer, had biological significance. ${ }^{240}$

\section{ANALYSIS OF THE PROCESS}

The FDA expected the PBOI to increase the effectiveness and the legitimacy of its decisions, ${ }^{241}$ but not all of its expectations were met. One anticipated benefit-a more expeditious process-did not materialize. The agency had underestimated the time and effort necessary to select PBOI members and to produce an initial decision.

Despite these problems, the PBOI can be a useful method of resolving cases presenting difficult issues of scientific judgment, particularly when those issues generate significant public interest. In such cases, the potential benefits of increased accuracy and legitinacy are likely to outweigh the costs associated with the PBOI. Further, the FDA can take some steps to lower those costs and thereby make the PBOI a more attractive option.

The experience of the aspartame and depo-provera proceedings supports these conclusions. The proceedings can be analyzed according to their three components: the pre-hearing, hearing, and post-hearing stages.

\section{A. The Pre-Hearing Process.}

The pre-hearing process has four stages. First, the FDA decides whether to assent to a request for a PBOI. It then fraines the issues the board will decide. Third, the FDA selects the members of the PBOI. Finally, the parties involved in the dispute participate in pre-hearing procedures, such as a pre-hearing conference.

1. Choice of the PBOI. The FDA evaluates requests for a PBOI without the benefit of published standards. ${ }^{242}$ According to FDA regula-

238. See supra notes $36-51$.

239. See supra notes $46-51$ and accompanying text (discussing extrapolation).

240. See supra notes $44-45$ and accompanying text (discussing biological significance).

241. See supra notes 113-32 and accompanying text.

242. In addition to a lack of standards, this stage may suffer from another problem. When a third party objects to approval of a petition for a food additive and asks for a PBOI, the person whose petition would be reviewed by the PBOI has no right to object to the use of that procedure. Antibiotic Drugs: General, 41 Fed. Reg. 51,706, 51,711-12 (1976). This situation occurred in the aspartame case, where the request for the PBOI was made by two third parties. See supra note 137 - 
tions, a PBOI will be held when the "Commissioner concludes, as a matter of discretion, that it is in the public interest to hold a public hearing before a Public Board of Inquiry."243

When the procedures for the PBOI were adopted, one critic predicted that, because of the lack of standards, "the apphication of [the PBOI procedures] is likely to be erratic and arbitrary." Further, he noted that "[i]f there are no standards for the Commissioner's selection of cases, its use will not create public confidence in the procedure."244

Although not erratic, the FDA's actions have confirmed the need for standards. In neither the aspartame nor the depo-provera case did the agency indicate why it approved the request for a PBOI.245 The FDA has since denied other requests for a PBOI on the grounds that its use will delay the regulatory process and that the administrative law judge has had experience with the issues presented, even if they are scientifically complex. ${ }^{246}$ In the context of these cases, the agency's explana-

43 and accompanying text. The FDA told Searle, the company that requested the additive regulation, that it had no right to prevent the agency from choosing the PBOI procedure. Interview with Robert Becker and Peter Safir, Counsel for Searle, Aspartame Hearing, in Washington, D.C. (June 25, 1985).

The FDA contends that its position is neither unfair nor unsound. The agency's intention is to "carefully consider the views of a [manufacturer] about the most appropriate forum . . . and [to consider denying] a request for an alternative form of hearing if . . such a procedure would prejudice the rights of [that person]." 41 Fed. Reg. 51,712 (1976). Further, the FDA correctly concludes that a company like Searle, whose petition has been granted, has no statutory right to a hearing. The Food, Drug, and Cosmetic Act (FDCA) grants the right to a hearing only if the petition for an additive regulation is denied. Id. As a result, the petitioning company has no right to block a request for a PBOI by another party.

This potential unfairness could be decreased if the FDA would adopt a set of criteria that specified when it would grant a request for a PBOI. See infra note 249 and accompanying text. One guideline that the FDA should adopt would indicate that a PBOI would not be granted if it prejudiced the ability of a manufacturer to have a fair and accurate hearing.

243. 21 C.F.R. $\S 13.1$ (a) (1985).

244. Thompson, Public Hearings-A View From The Bar, 32 Food DRug Cosm. L.J. 312,314 (1977).

245. See Aspartame: Ruling on Objections and Notice of Hearing Before a Public Board of Inquiry, 44 Fed. Reg. 31,716, 31,716-19 (1979) (FDA granted a PBOI for aspartame without explanation); Depo-Provera Hearing on Proposal to Refuse Approval of Supplemental New Drug Application, 44 Fed. Reg. 44,274, 44,274-76 (1979) (FDA ordered a PBOI for depo-provera without explanation).

246. See, e.g., Decision Denying Request for a Public Board of Inquiry on the Proposed Withdrawal of Cyclandelate (Cyclospasmol), Doc. No. 84N-0168 (1985). In this decision, the commissioner noted that:

[T] he issues presented by this proceeding are suitable for resolution by a formal evidentiary hearing .... This form of hearing has worked well in previous hearings involving the application of the regulatory requirements for adequate and well-controlled studies ... to particular drugs. Many of these hearings have involved difficult and complex issues. Through these hearings, the Administrative Law Judge has developed experience in handling the medical and legal issues presented by drug efficacy hearings that would be diffi- 
tions appear reasonable, ${ }^{247}$ but there have been informal indications that the FDA intends to reject all PBOI requests because of its experiences in the aspartame and depo-provera cases. ${ }^{248}$ If the agency has reached such a policy decision, it has done so without the benefit of public input and without publicly acknowledging its position.

Developing guidelines by which requests for a PBOI would be granted or denied would yield four benefits. First, the FDA would be able to consider carefully the benefits and costs of the PBOI and to obtain public input concerning them. Second, adopting criteria would encourage applicants to request the PBOI in appropriate cases. A third advantage is that those who applied for a PBOI would be protected to some extent against arbitrary agency action. ${ }^{249}$ Finally, such criteria would enhance public confidence in the procedure.

2. Formulation of the Issues. Once the FDA has decided to use the PBOI procedure, it specifies what questions, or "charges," the panel is to address. Critics have contended that there were two problems with the agency's choice of issues in the aspartame and depo-provera cases. ${ }^{250}$ One objection is that a PBOI should not be assigned the responsibility to

cult to match in any alternative forum .... Finally, establishing and conducting a Public

Board of Inquiry ... would cause unwarranted delay .... Id. at 2-3.

247. The FDA has been particularly concerned about delay because the requests for PBOIs have all been inade in cases where the agency wants to remove drugs from the market in light of the lack of evidence that they are effeetive. Copp and Campbell Interview, supra note 127. The drugs that the FDA wants to reinove from the market were approved by the agency before there was a statutory requirement that a manufacturer prove a drmg was effective to gain approval. See 21 U.S.C. $\S 355(b)(1)$ (1982) (requiring persons submitting applications for drug approval to disclose "full reports of investigations which have been made to show whether . . . such drug is effective in use"); Limiting Physician Freedom, supra note 32, at 803 (FDCA as interpreted by FDA requires submission of information froin which FDA can gauge a drug's effectiveness); see also 21 C.F.R. $\$ 314.1(10)$ (1984) (requiring that applications for new drug approval contain "full reports of adequate preclinical tests by all methods reasonably applicable to a determination of the safety and effectiveness of the drug under consideration"). Because Congress made the efficacy requirement retroactive, the issue in these cases is whether the inanufacturer now has adequate evidence of efficacy. The FDA has a legitinate interest in attennting to remove them as soon as possible because the drugs reinain on the inarket during the pendency of the hearing process. For a short history of the effectiveness requirement, see J. Mashaw \& R. Merrill, Administrative LaW: The American Public Law System 285-316 (2d ed. 1985).

248. Stribling Interview, supra note 129; Interview with Linda Horton, Attorney, FDA, in Washington, D.C. (June 24, 1985) [hereinafter Horton Interview]. The agency's dissatisfaction with the PBOI apparently is based on the difficulty of obtaining persons to serve on the panel and the length of time needed before a board reaches its decision. These problems are considered infra notes 276-300, 362-78 and accompanying text.

249. Cf. Davis, An Approach to Legal Control of the Police, 52 TEx. L. Rev. 703, 705 (1974) (suggesting efficacy of rulemaking procedure in regulating police activities).

250. See infra notes $254-55,262-65$ and accompanying text. 
make "regulatory" judgments. ${ }^{251}$ Second, because the FDA inevitably seems to assign it regulatory judgments, the PBOI is of doubtful utility. 252

The aspartame and depo-provera PBOIs were required to make both "scientific" and "regulatory" judgments. 253 Professor Vincent Brannigan has recommended that the FDA submit only "scientific questions" to a PBOI. ${ }^{254} \mathrm{He}$ doubts that the structure and makeup of a PBOI qualify it to make "regulatory decisions," because scientists lack the training or experience to analyze the policy questions involved in such issues. 255

Although Professor Brannigan is correct in stating that scientists do not necessarily have any expertise concerning the resolution of issues of regulatory judgment, ${ }^{256}$ it does not follow that the FDA should avoid submitting such issues to a PBOI. There are several reasons for allowing the PBOI to consider such issues. Although scientists do not necessarily have expertise in those matters, individual scientists-based on their experiences with other regulatory matters--might have significant insights to offer. In addition, regulatory judgments require an appreciation of the nature of scientific judgments and their relationship to regulation. ${ }^{257}$

251. See infra notes $254-55$ and accompanying text.

252. See infra notes 262-65 and accompanying text.

253. Some judgments were "scientific" because their resolution required the application of scientific knowledge and experience. For example, one issue was whether the ingestion of aspartame may induce brain tumors in rats. See supra note 148 and accompanying text. To answer this, the board had to evaluate the scientific reliability of the rat studies. See supra notes $27-56$ and accompanying text (description of judgmental nature of evaluation of scientific evidence). Other judgments were "regulatory" because they required the application of legal or policymaking knowledge or experience. See supra notes 27-37 and accompanying text. For example, one charge to the board was to determine whether aspartane should be approved for use in foods in light of the scientific evidence. See supra note 148 and accoinpanying text. This decision, which involved an application of the FDA's statutory standards of "safety," was clearly regulatory in character. See supra notes 46-51 and accompanying text.

254. Brannigan, The First FDA Public Board of Inquiry: The Aspartame Case, in LAW AND SCIENCE IN COLLABORATION, supra note 1, at 201. He therefore approves of the aspartame board's charge to determine whether the additive caused brain tumors in rats. Id. at 184, 201.

255. Id. at $184-85,188-89$. Thus he disapproves of the fact that the aspartame board was asked to determine whether aspartame should be allowed for use in foods. The same conclusion was reached in Note, The FDA's Publie Board of Inquiry and the Aspartame Decision, 58 IND. L.J. 627, 639 (1983) ("[The aspartame board] was required to make the legal determination of whether aspartame should be approved for inarketing instead of ... deciding to what extent, if any, aspartame is harmful.").

256. See McGarity, supra note 37, at 747-48 ("Scientists may decide a policy question one way for purposes of scientific analysis, while regulators may resolve it in an entirely different fashion for purposes of inplementing their statutory inandates.").

257. See supra note 37 and accompanying text. 
Scientists can help understand that interrelationship. ${ }^{258}$ Furthermore, because the PBOI is used in lieu of a formal evidentiary hearing, its legitimacy depends in part on offering participants the opportunity to comment on any relevant issue, including policy questions. Finally, because the PBOI's decision is only a recommendation, the commissioner will accept the PBOI's regulatory judgments only if the board can marshal persuasive reasons for them. If necessary, the commissioner can also hold a separate hearing to hear the individual views of participants concerning specific regulatory issues. ${ }^{259}$

Wlien the FDA submits a regulatory matter to a PBOI, it should ask the board two broad questions. First, it should ask the board to determine the probability that a chemical is safe in light of all the relevant evidence. In this way, the board will reach an overall scientific judgment that requires it to consider its answers to the other charges and, because scientific evaluations normally consist of probabilistic determinations, ${ }^{260}$ to respond in terms that scientists will find familiar. Tle second broad question the board should consider involves what action is justified by the board's conclusion concerning the probability of harm. This approach separates the question of scientific judgment, which concerns the probability of harm, from the regulatory question, which concerns the action the FDA ought to take. ${ }^{261}$

Nancy Buc, a former FDA general counsel, has argued that the PBOI has hittle practical benefit because its expertise is significantly, if not entirely, restricted to issues involving scientific judgment. 262 She contends that the "government cannot be informed solely by science, although it cannot govern without science."263 Her reason is that health and safety questions are too often matters of regulatory judgment. According to Buc, "there are so many inore [issues besides issues of science judgment] that ought to go into the business of governing, that a PBOI

258. The ... need for scientific analysis ... goes beyond the simple assembly and interpretation of existing data .... Beyond this, scientific expertise is necessary to recognize the need for new data accumulation to anticipate emerging issues, to point to possible or probable implications of new courses of action or changes of circumstance, to interpret for various audiences the scientific and technical content of political issues, and to provide access to decision makers to the best and latest technical information. . . . This is the content of . . . policy-centered and decision-oriented science . . . .

Grobstein, supra note 105 , at 129-30.

259. See 21 C.F.R. $\S 12.125$ (f) (1985) (commissioner may invite participants who appeal an initial decision to file briefs or make oral presentations).

260. See Mashaw, An Overview: Two Models of Regulatory Decision Making, in LAw AND SC1ENCE IN COLlaboration, supra note 1, at 17-18.

261. Id. at 18; NATIONAL RESEARCH COUNCIL COMMITTEE ON THE INSTITUTIONAL MEANS For AsSESSMENT of Risks to PUblic Health, Risk ASSESSMENT IN THE FEDERAL GoverNMENT: MANAging the PRocess 151 (1983).

262. Buc, Comment, in LAW AND Science IN COLlaboration, supra note 1, at 206.

263. Id. 
winds up as too small a piece of what the total process ought to be about."264 Similar criticisms have been made of the science court proposal. 265

These critics, however, underestimate the value of the PBOI. Even if it is not practical in the vast majority of the FDA's cases, some cases present significant and difficult issues of scientific judgment. In the case of aspartame, for example, the agency was asked to decide the safety of a food additive that would be widely used by the American public. ${ }^{266}$ Public interest in the issue was strong because the FDA had already removed two other artificial sweeteners from the market because they were allegedly unsafe. ${ }^{267}$ The depo-provera case generated the same degree of public interest because the drug had been approved as a contraceptive by almost every other country in the world. ${ }^{268}$

In these circumstances, the FDA gams two advantages from the PBOI process. The first is the opportunity to have a panel of experts analyze issues requiring scientific judgment. This may increase the accuracy of the decisionmaking process, ${ }^{269}$ even if the panel can offer no particular assistance to the agency on issues of regulatory judgment. ${ }^{270}$ Moreover, this advantage is present even if the FDA ultimately disagrees with the PBOI; to overrule the panel, the commissioner must be able to rebut the board's conclusions. Thus, the PBOI forces the FDA to take a "hard look" at the validity of the agency's position. ${ }^{271}$ Moreover, the participation of experts who are independent of the agency enhances the legitimacy of the agency's decisionmaking process. ${ }^{272}$ If the FDA is willmg to subject its decisions to this type of strict scrutiny, public confidence in agency decisionmaking should increase. Because the board's written decision and the transcript of its hearing are available for judicial review, ${ }^{273}$ the agency must have reasonable grounds for overruling the board's initial decision. 274

264. Id.

265. See supra note 90 and accompanying text.

266. See supra note 133 and accompanying text.

267. See supra notes $133-36$ and accompanying text.

268. See supra notes 194-98 and accompanying text.

269. See infra notes $320-46$ and accompanying text.

270. The panel, however, may be able to offer some assistance on these issues as well. See supra notes 257-58 and accompanying text.

271. See R. Pierce, S. Shapiro \& P. VerkulL, supra note 8, $\$ 7.5 .2$ (description of "hard look" review by federal courts).

272. See supra note 115 and accompanying text.

273. See infra notes $391-98$ and accompanying text.

274. See R. Pierce, S. Shapiro \& P. Verkuil, supra note 8, $\S 7.3$, at 358 (findings of hearing body are part of record that courts use to review agency decisions). 
Although the PBOI can help resolve regulatory issues, it is more useful for resolving scientific disputes. The FDA should consider this when it develops criteria to determine when a PBOI should be used.275 Cases that involve only regulatory issues probably are unsuitable for a PBOI. In those cases, the costs associated with a PBOI will probably exceed the benefits.

3. Selection of Board Members. After the FDA specifies the issues a PBOI will decide, it selects the board's members from the participants' nominees. ${ }^{276}$ Two aspects of this stage that require evaluation are, first, and most significantly, the delay caused by the difficulty of finding qualified scientists to serve as board members and, second, the belief of some commentators that the nomination process is potentially unfair and inconsistent with the purpose of the PBOI.

a. Identifying qualified board members. The difficulty of finding qualified board members significantly delayed the depo-provera hearing, the appointment process for which took over two years. ${ }^{277}$ It is impossible to measure the delay in the approval of aspartame that is attributable to the selection process because, after the first two stages, the FDA stayed the proceeding for over three years while it investigated the authenticity of Searle's test data. ${ }^{278}$

Finding persons qualified to serve is time-consuming for a number of reasons. Board members must pass the FDA's strict conflict-of-interest rules. ${ }^{279}$ These rules exclude many experts who worked previously for the coinpany whose product is the subject of the hearing or who published papers in which they took a position on some issue relevant to the hearing. ${ }^{280}$ In addition, only a limited number of persons have the skills

275. See supra notes $244-49$ and accompanying text (recommendation that FDA establish criteria for use of PBOI).

276. See supra note 14 and accompanying text.

277. The depo-provera hearing was announced in July 1979. Depo-Provera Hearing on Proposal to Refuse Approval of Supplemental New Drug Application, 44 Fed. Reg. 44,274 (1979). The board was not established, however, until September 1981. PBOI Report, supra note 200, at 39,638.

278. See supra notes $145-47$ and accompanying text.

279. See 21 C.F.R. $\$ 13.10$ (a) (1985) ("All members of a Board are . . subject to the conflict of interest rules applicable to special Government employees."); see generally REviEW PANEL ON NeW DRUg REgulation, DEPARTMENT OF HEALTH, EdUCATION, AND WELFARE, INTERIM REPORT: CONFLICTS OF INTEREST ON STANDING ADVISORY COMMITTEES OF THE BUREAU OF DRUGS, FDA 10-17 (1977) (summarizing FDA policy on conflicts of interest among advisory committee members).

280. Conflict-of-interest problems were prominent in both the aspartame and depo-provera cases. In the aspartame cases, Dr. Olney objected to the inclusion of Dr. Vernon Young on the PBOI because Young had coauthored articles with Searle researchers about chemicals other than aspartame. The commissioner dismissed the objection as being untimely. See Brannigan, supra note 254, at 186. In the depo-provera case, Upjohn objected to the inclusion of Dr. Paul Stolle, wlio had 
and scientific expertise that a PBOI requires. ${ }^{281}$ These include the ability to write an initial decision that is understandable to nonscientists, the capacity to communicate effectively with lawyers and other nonscientists, the manageinent skills to conduct a hearing, an interest in dealing with numierous details, and the willingness to make difficult decisions im controversial niatters. ${ }^{282}$ A final problen1 is that many qualified persons are unwilling to serve because of the tinie commitnient. ${ }^{283}$ Board members must read relevant FDA documents and scientific articles, ${ }^{284}$ participate in a hearing that lasts several days, ${ }^{285}$ and prepare an initial decision that can be of considerable length and complexity. ${ }^{286}$

Several steps could be taken to facilitate the selection of board members. For example, the FDA could mitigate the conflict-of-interest problenis by relying more on government scientists. The commissioner, who has the right to choose the chairperson, could select a government scientist for that position. ${ }^{287}$ Also, invitations to serve on the PBOI should come froin the commissioner or other high-ranking agency officials, thus indicating the importance of this service. Personal intervention of this type might convince reluctant nominees to serve. Finally, the agency could make the position more attractive by making board service less tinie-consuming. The FDA should authorize board meinbers to hire the equivalent of "law clerks," offer the board clerical support for the preparation of written decisions, and institute record management procedures to allow more efficient access to docuinents. ${ }^{288}$ Further, PBOIs

been an expert witness in a tort action that concerned contraceptives. To solve the objection, Dr. Stolle agreed to recuse himself from certain issues in the hearing. Copp and Campbell Interview, supra note 127.

281. In the aspartame case, the FDA, because of the difficulty in finding qualified persons, found it necessary to select two persons from the same institution. Both Dr. Vernon Young and Dr. Walle Dauta were froin the Massachusetts Institute of Technology. Interview with Marsha Gardner, Counsel for the Center for Food Safety \& Applied Nutrition, FDA, Aspartame Hearing, in Washington, D.C. (June 24, 1985) [liereinafter Gardner Interview].

282. Becker and Safir Interview, supra note 156; Stribling Interview, supra note 129; Telephone interview with Robert Temple, Director of Drug Research, FDA (July 1, 1985) [hereinafter Temple Interview].

283. Copp and Campbell Interview, supra note 127; Interview with Beverly Rothstein, Counsel for Aspartame PBOI, in Washington, D.C. (June 26, 1985) [hereinafter Rothstein Interview].

284. Rothstein Interview, supra note 283.

285. See supra notes $151,214-15$ and accompanying text.

286. The depo-provera initial decision, for example, is over two hundred pages long. PBOI Report, supra note 200; see infra notes 364,374-78 and accompanying text (discussing difficulty of writing initial decision).

287. See 21 C.F.R. $\$ 13.10$ (c) (1985). The Center for Drugs or the Center for Food Additives could also nominate government scientists. See id. $\$ \S 13.10(\mathrm{a}),(\mathrm{b})$; see generally supra note 14 (procedures for selection of board members). Many government scientists, however, may be as busy as tlieir private counterparts and therefore would also be unwilling to serve. Other government scientists may lack the necessary qualifications and professional stature to serve.

288. See infra notes $\mathbf{3 7 7 - 7 8}$ and accompanying text. 
can reduce their own responsibilities. For example, participants could be required to file pre-hearing briefs and written statements of their testimony to assist the board in evaluating the evidence. Moreover, boards could rely to a greater extent on their FDA-appointed legal advisor to formulate and write the PBOI's decision.289

Even if these steps are taken, the FDA will continue to have some difficulty in attracting board inembers. As a result, it is unlikely that the PBOI process can be used very often. This suggests that the FDA ought to restrict use of the PBOI to cases involving difficult issues of scientific judgment that are of significant interest to the public.

For this limited number of cases, however, the FDA should be able to recruit the necessary assistance. Moreover, the occasional use of the PBOI inay be sufficient to handle the number of controversies for which the procedure is appropriate. 290

b. Selecting board members. Some commentators have expressed concern about the FDA's method of choosing board members. ${ }^{291}$ Critics have noted that the commissioner can avoid choosing anyone nominated by the petitioner. ${ }^{292}$ Only one board member is chosen froin the combined nominations of the petitioner and the FDA division that will par-

289. Id. The FDA could take another action to improve the selection process and other aspects of the pre-hearing stage. To some degree, the delay took place because no one person was in charge of the PBOI process in the same manner that an ALJ is in charge of a formal hearing. The general counsel's office was responsible for negotiating the charges to the board; the commissioner's officc was responsible for selecting board members. This division of responsibility hampered both activities because no one was in a position to accelerate the process. As a solution, the commissioner should appoint a chairperson as soon as a PBOI is chosen as the appropriatc hearing method. The chairperson, along with the attorney-advisor for the board, would then be in a position to ensure a more efficient process. The chairperson could act in the same manner as an ALJ-managing the case and threatening to sanction any party who is dilatory.

290. The FDA has been able to resolve almost all controversies about new drugs as administrative matters. Dean Richard Merrill and Professor Jerry Mashaw report that the "agency and the applicant generally reach agreement on conditions for the release of a drug for which a formal NDA. has been filed; when the agency appears unlikely to be persuaded, the applicant typically never submits a completed NDA." J. MASHAW \& R. MERRILL, supra note 247, at 288 . As a result, the FDA has held only three formal hearings on a refusal to approve a new drug since 1962 .

Other formal evidentiary hearings have been held to determine whether drugs approved by the agency prior to 1962 can remain on the market. These hearings are necessary to determine whether drugs marketed prior to 1962 meet the additional requirement that a manufacturer must establish the efficacy, as well as the safety, of its drugs for FDA approval. Id. at 288-90. The FDA, however, has often avoided these hearings on the ground that the manufacturer failed to provide any evidence that its product was effective. Id. at 290; see generally supra notes 68-69 and accompanying text. Further, it is unlikely that this second type of hearing would be suitable for a PBOI because these cases rarely involve significant issues of scientific judgment. See supra notes 246-47 and accompanying text.

291. See Thompson, supra note 244 , at $314-15$; Note, supra note 255 , at 644 .

292. The commissioner selects one board member from the nominations submitted by the petitioner and the FDA staff involved in the hearing. A second person is chosen from the nomination 
ticipate in the hearing. ${ }^{293}$ If the petitioner is opposing a decision by the agency to approve a product, the petitioner and the FDA division will have antagonistic interests. Failure to choose a nominee of the petitioner in this situation could thus threaten the legitimacy of the process. The solution would be to change the nomination process so that the cominissioner selects one nominee submitted by those supporting the FDA's action, one from those opposing the action, and a third of his choice.294

Another source of concern is the belief that a noinination process is inappropriate for this type of hearing body. By using this process, the FDA allows participants to recommend persons they beheve will support their position. ${ }^{295}$ One commentator is concerned that the procedure will be "open to controversy" because it "places potential partisans in positions that should be [held by] neutral [persons]."296 The commentator's solution is to have an independent body, such as the National Acadeiny of Sciences, select the board members. ${ }^{297}$

This coininentator's premise is unsound. The participants' role in selecting the PBOI's members enhances the board's legitimacy, as it does in the case of arbitration boards. ${ }^{298}$ Further, the FDA's stringent conflict-of-interest rules sufficiently guarantee the neutrality of board members because they exclude anyone who has apparently prejudged the outcoine of the controversy. ${ }^{299}$ Moreover, administrative decisionmakers are traditionally not disqualified because of their views on broad pohicy matters, as opposed to prejudgment of particular facts. ${ }^{300}$ It is entirely consistent with this traditional approach that, in the context of the PBOI, a party is free to nominate a scientist whose general views about scientific controversies appear favorable to the party's position.

4. Other Pre-Hearing Procedures. Four other aspects of the prehearing stage require brief examination: whether parties should have additional discovery rights, whether the use of a pre-hearing conference should be required, whether the role of lawyers should be deemphasized, and whether the PBOI creates unacceptable adininistrative burdens.

list prepared by the other participants in the proceeding. The commissioner, in his discretion, chooses the third person, who is the chairperson. See supra notes 15-17 and accompanying text.

293. See supra notes $14-18$ and accompanying text.

294. See Thompson, supra note 244 , at $314-15$ (suggesting this solution).

295. Becker and Safir Interview, supra note 156; Note, supra note 255 , at 644 .

296. Note, supra note 255 , at 644 .

297. Id. at $644-45$.

298. See R. Gorman, Basic Text on labor Law: Unionization and Collective BarGAINING 542 (1976) (discussing arbitration procedures).

299. See supra note 279 and accompanying text.

300. See R. PIERCE, S. SHAPIRO \& P. VERKUIL, supra note $8, \S 9.2 .2$ (administrators should not be disqualified for their views on broad policy questions). 
Existing pre-hearing procedures include two discovery requireinents. Submissions for the hearing record are filed with the FDA before the hearing, and parties receive either a copy or a notification of such filings. ${ }^{301}$ Parties are also required to specify the nature of the arguments they intend to present, and to identify their witnesses and the evidence on which they intend to rely. ${ }^{302}$

Some commentators would have the FDA consider whether additional discovery procedures, such as written interrogatories, would be useful. ${ }^{303}$ Based on the FDA's experience in the aspartame and depoprovera cases, however, additional discovery appears unnecessary. In neither case did it appear that any party was disadvantaged or surprised by arguments from other parties. Disputes of this type concern the evaluation of scientific studies that are publicly available froin the agency or in the literature; ${ }^{304}$ as a result, the FDA's requirement that parties indicate the evidence on which they intend to rely is sufficient to avoid unfair surprise.

In both the aspartaine and depo-provera cases, the boards went beyond required discovery and held pre-hearing conferences. ${ }^{305}$ These conferences were used to allocate time for each presentation, to consider the other procedures to be used in the hearing, and to emphasize the board's desire to avoid an adversarial proceeding. ${ }^{306}$ Those involved believed the conferences contributed to the success of the hearing process. ${ }^{307}$

Some observers are disappointed that lawyers played such a prominent role in the pre-hearing process, believing that it detracted from the "scientific" nature of the proceedings and contributed to the delays that occurred. ${ }^{308}$ Other observers beheve the participation of attorneys is essential if a hearing is to be well-run and well-organized. ${ }^{309}$ Lawyers in each case helped negotiate the issues that would be heard by the board, ${ }^{310}$ established the procedures that the board would use, ${ }^{311}$ submit-

301. 21 C.F.R. $\$ 13.20$ (1985).

302. Id. $\S 13.25$.

303. See, e.g., Koch, Discovery in Rulemaking, 1977 DuKE L.J. 295, 345 (advocating the broadening of information gathering procedures).

304. See supra notes 27-56 and accompanying text.

305. See Depo-Provera Sterile Aqueous Suspension; Notice of Prehearing Conference on Proposal to Refuse Approval of Supplemental New Drug Application, 47 Fed. Reg. 36,470 (1982); Rothstein Interview, supra note 283.

306. Rothstein Interview, supra note 283; Stribling Interview, supra note 129.

307. Rothstein Interview, supra note 283; Stribling Interview, supra note 129.

308. Hutt Interview, supra note 122; cf. Brannigan, supra note 254, at 182-84 (lawyers involved in aspartame PBOI framed the issues so that a legal rather than scientific judgment would be made). 309. See, e.g., Copp and Campbell Interview, supra note 127.

310. See Brannigan, supra note 254 , at $182-84$ (discussing events that framed the issues for aspartame hearings). 
ted documents and prepared witnesses, ${ }^{312}$ and monitored the compliance of participants with the procedural regulations. ${ }^{313}$

There is no evidence that the legal maneuvering that occurred during the pre-trial process caused significant delay. Furthernnore, because lawyers are trained to orchestrate the presentation of evidence, their participation probably helped to organize the PBOI process. Finally, it is doubtful that the FDA could limit the participation of lawyers in the pretrial process without discouraging the use of the PBOI or possibly infringing the due process rights of the parties. ${ }^{314}$

A final concern is that a PBOI involves "an administrative nightmare." 315 Indeed, a PBOI is costly to administer. These costs include the transaction and salary costs of hiring the board members as special employees of the agency, ${ }^{316}$ the transaction and logistical costs of a PBOI hearing, ${ }^{317}$ and the cost of assigning one or more lawyers to the board as counsel on legal and procedural issues. 318

In light of these expenses, the FDA might use "cost" as one of its criteria for determining whether to convene a PBOI. At the same time, the agency should be able to decrease its transaction costs as it becomes more experienced in administering a PBOI. For example, one cause of high transaction costs has been the inexperience of personnel in the comnissioner's office in managing PBOI-type meetings. ${ }^{319}$

The pre-hearing stage facilitates an orderly and effective hearing, but at the cost of considerable delay. Many of the causes for the delay can be remedied, but finding board meinbers will continue to be a problem. The advantages of the PBOI must be weighed against that disadvantage.

311. See, e.g., Letter from J. C. Stucki, Vice President for Pharmaceutical Research, Upjohn Company, to Linda Quinones, Chief of FDA Documents Branch (October 15, 1981) (discussing procedures and timetables for depo-provera PBOI); Letter from Diane Silberstein, Counsel to the National Women's Health Network, to Dr. Judith Weisz, Chairperson, Depo-Provera PBOI (October 26, 1982) (discussing clarification of procedures).

312. Copp aud Campbell Interview, supra note 127.

313. See Brannigan, supra note 254, at 192-94 (description of Upjohu's objections to Dr. Olney's submissions). The "policing" function even included negotiations concerning whether or not the depo-provera hearing could be videotaped. See Letter from Mark Novitch, M.D., FDA Deputy Commissioner, to William B. Schultz, Counsel to the Public Citizen Litigation Group (Jan. 5, 1983) (denying appeal from ruling that no videotaping could take place).

314. See generally R. PIERCE, S. Shapiro \& P. Verkuil, supra note $8, \S 6.3$ (discussing due process clause as source of procedural requirements).

315. Stribling Interview, supra note 129.

316. See 21 C.F.R. $\$ 13.10(\mathrm{e})$ (1985).

317. Stribling Interview, supra note 129.

318. See 21 C.F.R. $\S 13.15$ (b) (1985) (administrative support will only be provided by the offices of the commissioner and the chief counsel for FDA).

319. Horton Interview, supra note 248. 


\section{B. The Hearing Process.}

1. Quality of the Process. The aspartame and depo-provera hearings were both noteworthy for the depth and sophistication of the scientific presentations and discussions. One commentator has called the aspartame hearing " $a$ model scientific debate" in which " $[t]$ he issues were presented sharply." 320 Participants were particularly impressed that the board members were familiar enough with the evidence that they could correct the misstatements of witnesses. ${ }^{321}$

This aspect of the PBOI distinguishes it from the FDA's other methods of obtaining scientific input. The PBOIs have been more successful in producing a thorough review of the issues than most advisory committees have been, and for a number of reasons. Witnesses before an advisory committee often present only background information..$^{322} \mathrm{Be}$ cause these presentations precede the FDA's decision, they may also fail to address issues that become important later in the decisionmaking process. ${ }^{323}$ Furthermore, many advisory committee members are not wellbriefed on the documents or scientific hiterature relevant to the presentations. As a result, the witnesses and committee members do not interact as productively as in PBOIs. ${ }^{324}$ PBOI members are also likely to have expertise in the specific matters under discussion; advisory committee members, $\mathrm{m}$ contrast, are likely to be generahists because they are picked to represent a broader range of expertise. ${ }^{325}$ In addition, advisory committee meetings only last for several hours, ${ }^{326}$ thereby himiting the attention that can be given to an issue. Finally, advisory committee members sometimes view their role as representing the interests of some constituency, such as a particular group of physicians. ${ }^{327}$ Board members, in contrast, have been praised for their impartiality. ${ }^{328}$

320. Brannigan, supra note 254 , at 194 . Another commentator concluded that "[ $t]$ he board was successful in crystalizing and narrowing the issues and brought independent expert assessment into the decisionmaking process." Note, supra note 255, at 636-37.

321. See, e.g., Stribling Interview, supra note 129.

322. Temple Interview, supra note 282.

323. $I d$.

324. See USE OF STANDing ADVisory COMMITTEES, supra note 100, at 81 (advisory committee members often are prepared inadequately for meetings); see also Gardner Interview, supra note 281; Stribling Interview, supra note 129.

325. See supra note 122 and accompanying text; see also Hoffman, The FDA's New Forms of Public Hearing-Choosing Among the Alternatives, 32 Food DRUG CoSM. L.J. 330, 337 (1977) (advisory committee is ad hoc in character); Becker \& Safir Interview, supra note 156; Sobel Interview, supra note 227.

326. USE OF STANDING ADVISORY COMmITTEes, supra note 100, at 97-100.

327. Copp and Campbell Interview, supra note 127.

328. Temple Interview, supra note 282. 
The differences identified between PBOIs and advisory committees affect the type of advice the FDA ultimately receives. In the advisory committee setting, committee ineinbers give the agency their impressions or opinions based on a brief review of the available evidence and on their own familiarity with the controversy. ${ }^{329}$ Moreover, the results of advisory committee meetings are usually reported in the form of minutes kept by an FDA enployee or in other documents that briefly suinmarize the disposition of a inatter. ${ }^{330}$ These reports may not identify clearly either the questions the FDA posed or the specific answers the committee formulated and the basis for those answers. ${ }^{331}$ Meinbers of the PBOI, in contrast, offer the FDA an expert assessinent of the relevant evidence in an accountable manner-the PBOI scientists are required to defend their judgments in a written explanation and evaluation of the relevant scientific evidence. ${ }^{332}$

Soine of the disadvantages of advisory committees could be overcoine if the FDA raised the standard of performance for committee members. ${ }^{333}$ The advisory coinmittee, however, might still lack specialists in the particular fields involved in a controversy. Moreover, participants are unlikely to submit to an advisory committee hearing uuless the FDA requires separation of functions and prohibits ex parte contacts. ${ }^{334}$ Those restrictions apply to a PBOI, but they do not currently apply to an advisory committee hearing. ${ }^{335}$

Many of the advantages of a PBOI may also be obtained by consulting an institution like the NAS-NRC. As one commentator recently reported: "The NAS has a unique status as an independent, congressionally chartered, and prestigious institution with a good record in providing advice on science and technology to the federal governinent, including advice on regulatory processes." 336 As a general matter, however, NAS-NRC committees do not use the same type of hearing process

329. Use OF STANDING ADVISORY COMMiTTEes, supra note 100, at 80-81, 104-07.

330. Id. at 109-13.

331. Id. at 113. For example, the chairperson of the depo-provera PBOI reported that she was unable to determine the basis for advisory committee recommendations concerning depo-provera from the available documentation.

332. 21 C.F.R. $\$ \S 13.30$ (e),(i) (1985).

333. See HEIV FINAL REPORT, supra note 123, at 57-59 (committees should assign certain matters as "primary reviews" to individual members, who would prepare questions about data received prior to the meetings).

334. See generally R. Pierce, S. Shapiro \& P. VerkuiL, supra note $8, \S 9.3$ (discussing ex parte contacts and informal rulemaking).

335. Compare 21 C.F.R. $\S 13.15$ (1985) (PBOI separation of functions and ex parte prohibitions) with 21 C.F.R. $\S 14.29$ (1985) (establishing advisory committee hearing procedures, which do not include requirement of separation of functions or prohibition on ex parte contacts).

336. Grobstein, supra note 105 , at 133. 
as a PBOI. ${ }^{337}$ NAS-NRC review is also more expensive than a PBOI. ${ }^{338}$ Finally, through a PBOI the FDA obtains expert, independent advice as part of its own hearing process; the NAS-NRC option would not serve the same purpose. ${ }^{339}$

A PBOI has several advantages over formal evidentiary hearings. First, PBOI members are more likely to know and understand the scientific evidence before the hearing begins. ${ }^{340}$ Unlike an ALJ, board members need to prepare for only one hearing, and their professional careers have been spent reading and understanding this type of evidence. As a result, the board members are better able to question witnesses, particularly on ambiguities or limitations in the data. ${ }^{341}$

In addition, outstanding scientists are likely to participate as witnesses im a PBOI because it is nonadversarial; many scientists are unwilling to testify in a formal evidentiary hearing because of the adversarial nature of that process. ${ }^{342}$ Scientists prefer to operate according to traditional scientific methods, which stress collegiality. ${ }^{343}$

A third advantage of the PBOI is that it is more likely than an adversarial proceeding to examine ill-defined issues. Many scientists beheve that there is a tendency for lawyers, and for traditional hearings, to focus only on questions that can be clearly delineated. ${ }^{344}$

Fourth, a PBOI is more likely than an ALJ to consider whether the FDA has a sound scientific basis for its actions. Most persons who challenge FDA actions beheve they have little or no chance of prevailing before the ALJ because he reportedly has never decided against the agency. ${ }^{345}$ One reason for this pattern is that the agency takes actions that lead to a hearing only when it beheves it has a strong legal case. Because the ALJ has a legal orientation, rather than a scientific orientation, the agency has always prevailed. ${ }^{346}$

A PBOI has several potential limitations, however, that must be bal-

337. See id. at 118-22, 127 (describing the hearing process used in NAS-NRC committees).

338. See supra note 105 and accompanying text.

339. See supra notes 6-12 and accompanying text.

340. Rothstein Interview, supra note 283.

341. Copp and Campbell Interview, supra note 127; see supra notes 178-79 and accompanying text.

342. Gardner Interview, supra note 281; Stribling Interview, supra note 129.

343. See McGarity \& Shapiro, supra note 32 , at 841 (scientific community routinely subjects results and methods to both formal and informal review).

344. Temple Interview, supra note 282.

345. Becker and Safir Interview, supra note 156; Copp and Campbell Interview, supra note 127; Hutt Interview, supra note 122.

346. Copp and Campbell Interview, supra note 127. 
anced against these advantages. ${ }^{347}$ The ability of board members to conduct a hearing depends on their level of expertise. Thus, one disadvantage of a PBOI is that its success depends on the FDA's ability to recruit able scientists as board members. ${ }^{348}$

A second disadvantage is that a board's expertise and the issues before it may be mismatched. In the aspartame case, for example, board members were chosen for their expertise in neurotoxicity. ${ }^{349}$ After the board members were selected, the FDA asked the PBOI to investigate an issue that required a different type of expertise. ${ }^{350}$ This problem could be minimized, however, by hiring persons with the necessary expertise as consultants to the board. ${ }^{351}$

A final limitation is that the commissioner may not appreciate the full extent of the debate that occurred during a PBOI hearing from the post-hearing documents submitted by the parties or from other parts of the hearing record. Because the quality of this debate is one of the important advantages of a PBOI, the commissioner should consider attending the hearing itself. In this way, the commisioner could ask questions, take part in the dialogue, and obtain a more complete and accurate understanding of the issues. ${ }^{352}$

347. Some may argue that the PBOI process is a less desirable alternative for the very reason that it is nonadversarial, and that an opportunity to challenge the admissibility of evidence is essential for preventing erroneous imformation from entering the record, while cross-examination is required to alert the decisionmaker to errors in testimony. One response is that parties could be given expanded rights to cross-examine witnesses and object to the inclusion of irrelevant or immaterial evidence. Adversarial procedures are not necessary for a PBOI, though, because board members are experts, with specific knowledge about a particular controversy. Thus, they are more likely than an ALJ to recognize incorrect information. Moreover, scientists are trained to identify mistakes and biases in each other's work; the scientific inethod is based on a tradition in which each scientist's work is subject to formal and informal review by other scientists. When the members of a PBOI conduct a hearing, they are engaged in the same process. Finally, there may be little practical difference between a PBOI and a formal hearing in terms of the types of evidence admitted because ALJs coinmonly allow most types of evidence to be admitted to avoid possible reversal.

348. The FDA has faced some difficulty in recruiting qualified persons to serve on PBOIs. See supra notes $277-90$ and accompanying text.

349. The inembers of the aspartame panel were selected when the only issues that were to be addressed concerned neurotoxicity; questions concerning aspartame's potential to cause brain tumors arose after the board had been selected. See Coinmissioner's Final Decision, supra note 139, at $38,286$.

350. The board was asked to determine whether rats who were fed aspartame developed brain tumors. Aspartame PBOI Decision, supra note 159, at 39. The eommissioner overruled the board concerning its conclusions about the rat studies. See supra notes 174-82 and accoinpanying text. Given that the commissioner found that some of the board's conclnsions concerning the rat studies contained methodological errors, see supra notes 178-82 and accompanying text, the board was probably hampered by its lack of expertise. See Peck, Comment, in LAW AND SCIENCE IN CollabORATION, supra note 1, at 209.

351. See 21 C.F.R. $§ 13.30(f)$ (1985) (board's authority to consult with experts).

352. Telephone interview with Richard Merrill, former FDA general counsel (Aug. 15, 1985). Quite understandably, the commissioner might be reluctant to attend a PBOI because of its length. 
2. Flexibility of the Process. A PBOI "may consult with any person who it concludes may have information or views relevant to the issues" during a hearing, ${ }^{353}$ and it may call a second hearing "if the Chairman concludes that it is needed to fully and fairly present information that cannot otherwise adequately be considered and to properly resolve the issues." 354 These features add to the board's flexibility, allowing it to respond to any new scientific evidence that develops during the hearing process, ${ }^{355}$ and to obtain additional inforunation concerning issues that are not resolved in the first hearing. ${ }^{356}$

3. Open Nature of the Process. A final advantage of the PBOI process is that it permits broad participation. In the depo-provera hearing, for example, over forty persons made presentations. These included representatives of the World Health Organization, the International Planned Parenthood Federation, the United States Agency for International Development, the Women's National Health Network, the Health Research Group, the Institute for the Study of Medical Ethics, and the American College of Obstetricians and Gynecologists. ${ }^{357}$ Although there were only a few nonparty participants in the aspartame proceeding, they included scientists who voluntarily appeared because of their interest and

The aspartame hearing lasted three days, and the depo-provera hearing lasted five days. See supra notes 151, 214 and accompanying text. An alternative would be to have direct communication between the board and the commissioner upon submission of the final decision. The time-commitment problem might also be addressed by changing the nature of the PBOI. The FDA's rules currently provide that a party entitled to a formal hearing can request instead a hearing before the commissioner. The commissioner could appoint independent scientists to assist him in the hearing process, including the preparation of his decision. This combination of the PBOI process and the commissioner's final decision should be more efficient because it would eliminate one step in the hearing process, decrease many of the administrative burdens that have delayed the PBOI process, and invite a collegial dialogue between the commissioner and independent, expert scientists.

353. 21 C.F.R. $\$ 13.30(f)$ (1985).

354. Id. $\S 13.30(\mathrm{e})$.

355. In the aspartame case, for example, a study suggesting that aspartame had neurotoxic properties was completed after the FDA had selected the PBOI. The board solicited additional submissions of data because these "new questions arose." See PBOI Report, supra note 200, at 3; see also supra note 350 and accompanying text.

356. In the depo-provera case, for example, the board was presented with evidence of carcinomas in two monkeys that were given depo-provera. The carcinomas developed in a location wherc such tumors were not known to occur spontaneously, which suggested that their development was related to the drug. This inference was contradicted by testimony that another study had found a spontaneous tumor in that unusual location. After the first hearing was completed, the board felt it could not reach a decision without determining the validity of the second study. As a result, the board hired a group of pathologists to verify whether the spontaneous tumor in the second study was of the same type and in the same location as the tumors in depo-provera monkeys. The board scheduled a second hearing to receive the report of the pathologists. See Depo-Provera Sterile Aqueous Suspension; Time and Place of Second Hcaring, 48 Fed. Reg. 31,910 (1983); Stribling Interview, supra note 129.

357. See supra note 209 and accompanying text. 
expertise in the matter. ${ }^{358}$ Based on these experiences, the PBOI appears to offer a better forum than advisory committees or formal hearings for broad-based nonparty participation.

FDA rules provide that any interested person may appear and make a presentation before an advisory committee, a formal hearing, or a PBOI. ${ }^{359}$ The informal PBOI is particularly well-suited to receiving input from scientists and others. Participants need not retain a lawyer to make a presentation, and the nonlegal nature of the hearing makes it less intimidating. ${ }^{360}$ Moreover, unlike a short advisory committee meeting, ${ }^{361}$ the PBOI process can be long enough to accommodate even a large number of participants. Because it convenes after the FDA has reached a decision, a PBOI can scrutinize rather than merely recommend a decision, and it is also likely to attract more public attention than an advisory committee.

\section{The Post-Hearing Process.}

The post-hearing process involves an initial decision by the PBOI and a final decision by the commissioner. Three aspects of this process should be examined: the time delay that occurs, the effect of the board's inattention to traditional legal procedures, and the commissioner's standard of review.

1. Time Delays. The preparation of the initial decision has caused delays in the PBOI process. Table II indicates the time periods between the start of the PBOI hearing, the date of the initial decision, and the date of the commissioner's decision (in the aspartame case). ${ }^{362}$ The depo-provera board took a considerably longer time (twenty-one months) to produce an initial decision than did the aspartame board (nine months). Nevertheless, Searle regarded even that delay as inappropriate-shortly before the board issued its decision, the company had filed suit to force the board to complete its decision. ${ }^{363}$

358. See supra note 143 and accompanying text.

359. 21 C.F.R. $\$ 12.40$ (1985); see USE OF STANDING CoMmITTEES, supra note 100 , at 103 (public interest representatives and individual consumers may address advisory committees if they have notified the FDA in advance).

360. See supra note 342 and accompanying text.

361. See supra note 326 and accompanying text.

362. Commissioner's Final Decision, supra note 139, at 38,286.

363. Becker and Safir Interview, supra note 156. 
Table II - Time Delays

\begin{tabular}{lll}
\hline Date hearing started & Depo-Provera & Aspartame \\
\hline Date of initial decision & January 1983 & January 1980 \\
\hline Time elapsed & October 1984 & October 1980 \\
\hline Date of final decision & 21 months & 9 months \\
\hline Total time elapsed & & July 1981 \\
\hline
\end{tabular}

Several factors led to these delays. Board members held other fulltime positions with their own time-consuming responsibilities. Further, with one exception, members had no one to assist them in preparing their decision. ${ }^{364}$ Board members were also geographically scattered and, as a result, could meet only sporadically. ${ }^{365}$

Difficulty in finding documents has also slowed the process. The chairperson of the depo-provera board called this problem a "mightmare."366 The FDA files documents in the order received. ${ }^{367}$ Although it gives each document a number, the agency has no cataloging system or other means by which to retrieve documents efficiently. ${ }^{368}$ As a result, a PBOI cannot be certain that it has reviewed all submissions pertaining to any particular issue without examining all of the documents filed. In the depo-provera case, these numbered into the thousands. ${ }^{369}$ Moreover, the search for a specific document can be time-consuming. For example, the depo-provera board found that the FDA had no index of advisory committee minutes. The board therefore had to search all of the minutes filed by the committee to locate the ones it wanted. ${ }^{370}$

Besides these general problems, the delay in the depo-provera case had three additional sources. The depo-provera board was asked to decide a broader array of issues than the aspartane board. ${ }^{371}$ Moreover,

364. The depo-provera PBOI chairperson did have the assistance of a graduate student from her institution. PBOI Report, supra note 200, at 5. The time demands are aggravated by the fact that the high quality scientists that the FDA seeks for the board are particularly busy. Cf. supra notes 283-87 and accompanying text (scientists unwilling to serve on PBOIs because of time constraints).

365. PBOI Report, supra note 200, at 5 n.3.

366. Telephone interview with Judith Weisz, M.D., chairperson of the depo-provera PBOI (August 15, 1985) [hereinafter Weisz Interview].

367. Id.

368. Id.

369. See infra note 373 and accompanying text.

370. Weisz Interview, supra note 366.

371. Compare supra notes 230-33 and accompanying text (depo-provera charges) with supra note 148 and accompanying text (aspartame charges). 
the FDA had been considering the depo-provera case for over eighteen years before the board was convened. ${ }^{372}$ As a result, there was a lengthy administrative record for the board to consider, as well as an extensive scientific literature. For example, the board reported that: "In September, 1983, when we began, the documents in the administrative record in this matter occupied approximately 45 linear feet of shelf space. At the time of the submission of our report, the documents occupy approximately 54 linear feet." 373

The scope of the depo-provera case is reflected in the length of the mitial decision, which covers nearly two hundred pages. ${ }^{374}$ In contrast, the aspartame initial decision is fifty pages long. ${ }^{375}$ The other factor that delayed the depo-provera board was the illness of one member, who was unable to assist in writing the report. ${ }^{376}$

Because of the peculiar problems faced by the depo-provera PBOI, the time delay in the aspartame case may indicate more accurately the length of time future PBOIs will need to prepare their decisions. Moreover, the FDA can take several steps to speed the process. The most important change would be to authorize board members to hire graduate students or others to serve the same function that law clerks serve for an ALJ or trial judge. The FDA could also offer the board clerical support or authorize board members to obtain it. Participants could be required to file pre-hearing briefs, written statements of their testimony, and a joimt appendix listing the documents upon which they would rely. These and similar requirements could help the board organize the issues and evidence. ${ }^{377}$ Furtherinore, the FDA could institute record management procedures that would improve access to docuinents. Finally, the board's legal advisor, an FDA attorney, might take a more active role in helping the board write its report, perhaps drafting part of the report under board supervision. ${ }^{378}$

Even if the FDA makes the improvements suggested here, the use of a PBOI may cause some delay. Consequently, the potential time delay slould be one factor considered in determining whether to grant a request for a PBOI. The FDA should also consider whether a case

372. See supra notes $199-209$ and accompanying text.

373. PBOI Report, supra note 200, at 4 n.2.

374. Id.

375. See Aspartame PBOI Decision, supra note 159. The aspartame decision, however, is insufficiently documented. See infra note 380 and accompanying text.

376. PBOI Report, supra note 200, at 5 n.4, 181.

377. See Copp and Campbell Interview, supra note 127; Rothstein Interview, supra note 283.

378. The attorneys who advised the boards apparently played a limited role in preparing the initial decisions. The decisions themselves were written entirely by the boards. Rothstein Interview, supra note 283; Stribling Interview, supra note 129. 
presents so many unresolved issues that a PBOI would be as unwieldy as it was in the depo-provera matter.

2. Inattention to Traditional Procedures. The aspartame PBOI has been criticized for its disregard of traditional legal procedures. ${ }^{379}$ The board's inost significant oversight was its failure to provide any citations in its initial decision. ${ }^{380}$ No one at the FDA anticipated that the board would issue a decision without footnotes, while the board itself did not consider the footnotes to be necessary. ${ }^{381}$ The FDA had corrected this problen by the time of the depo-provera board's initial decision by informing the board of the need for supporting citations. ${ }^{382}$

Professor Brannigan has argued that another problem is the absence of an "appropriate, usable record" for the proceeding. ${ }^{383}$ Although "the office of the hearing clerk [at the FDA] maintains a reasonably efficient, cumulative record of the entire proceeding ... it is impossible to determine what portion of the 162 volumes constitutes the hearing record." Brannigan contrasts this situation to his experiences with adjudicatory hearings at the Consumer Product Safety Commission, where "an appropriate, usable record was made and preserved."384 This criticism, however, is not appropriately directed at the PBOI procedure, because the FDA establishes the same type of record for both a PBOI and a fornal evidentiary hearing. ${ }^{385}$

Professor Brannigan also objects that the FDA has failed to explain why witnesses were not under oath, why slides used by some witnesses during their testimony were not made part of the record, and why two board inembers visited the Searle laboratories after the hearing was over to view tissue samples stored there. ${ }^{386}$ Concerning the last event, Brannigan notes that the observations of board members during their visit are

379. See, e.g., Brannigan, supra note 254, at 194-95, 199-200 (witnesses were not under oath, slides used in presentations were not made part of record, and hearing record was not distinguished from other documents); Buc, supra note 262, at 205 (by not following regular legal procedure, PBOI created "utter mess" for potential litigants).

380. See Aspartame PBOI Decision, supra note 159.

381. Rothstein Interview, supra note 283.

382. Stribling Interview, supra note 130.

383. Brannigan, supra note 254 , at 200.

384. Id. at 199-200.

385. The record for a PBOI consists of all Federal Register notices, all written submissions, the transcripts of all hearings, and the initial decision, including the documents it cites in support of its conclusions. A record for a formal hearing consists of all of these documents and any other documentary evidence submitted during the hearing. Compare 21 C.F.R. $\S 13.40$ (PBOI record) with id. $\S \S 12.94,12.100$ (formal hearing record). Because of its informal nature, the PBOI does not include any procedure by which the board rules on the admissibility of evidence. See supra notes 21-26 and accompanying text.

386. Brannigan, supra note 254 , at 194-95. 
"not evidence of record, unless their observations, as expressed in the [initial decision], are evidence."387 The FDA could easily remedy Professor Brannigan's complaints. Witnesses should be required to take oaths, copies of slides used by witnesses should be included in the record, and board inembers should be required to summarize their findings concerning any on-site visit for inclusion in the record. These changes would inprove the accountability of the board without interfering with the PBOI process.

Even if these changes are made, however, Professor Brannigan and others may still be unsatisfied. Their true objection to the PBOI process appears to be that it does not include all of the procedures used in a formal evidentiary hearing. Thus, soine critics have objected to the lack of an opportunity for cross-examination. ${ }^{388}$ Similarly, Professor Brannigan objects that nembers of a PBOI have engaged in on-site inspection from which the participants in the hearing process were absent. 389 As previously noted, however, the traditional procedures of a formal hearing process are unnecessary when scientific specialists are employed. ${ }^{390} \mathrm{Se}$ lecting board nembers for their familiarity with both the specific subject matter and the particular controversy being resolved sufficiently guarantees accurate decisionmaking.

3. Appropriate Standard of Review. The final question relevant at this stage of the process is the proper scope of the commissioner's review of PBOI decisions. In the traditional hearing process, if an agency and an ALJ disagree with respect to a finding of fact, the agency's finding receives deference on judicial review; the reviewing court considers the ALJ's findings only in determining whether the agency's finding is supported by the record as a whole. ${ }^{391}$ Some cominentators have suggested that the special status of the PBOI inay require different treatment. ${ }^{392}$ They argue that "the entire rationale for convening a board of experts collapses if their opinion carries no more weight than that of an adıninistrative law judge" 393 and that, "if an expert advisory group, such as the board, is only given lip service, then utilization of the board becoines merely a wasteful step in a repetitious process of regulation." ${ }^{394}$ Further, the lack of deference inight discourage scientists froin accepting appoint-

387. Id. at 195.

388. See supra note 347.

389. See supra notes $386-87$ and accompanying text.

390. See supra note 347.

391. See R. Pierce, S. Shapiro \& P. Verkuil, supra note $8, \S 7.3-1$, at 358 (1985).

392. See Brannigan, supra note 254 , at 197-99; Note, supra note 255 , at $646-48$.

393. Brannigan, supra note 254 , at 198.

394. Note, supra note 255 , at 647. 
ments to the board. Accordingly, these commentators propose that the board's conclusions be given "the status of a jury finding, to be overturned only if no reasonable person could agree with the panel," ${ }^{395}$ or that the "factual determinations of the board should ... have a presumption of validity with a clear error standard of review."396

These suggestions, although meritorious, raise a problein of their own. Congress has given the commissioner the responsibility to implement the FDCA, making the commissioner legally and politically responsible for the agency's actions. Consequently, the commissioner should be free to reach a conclusion different than that found by the PBOI if cogent reasoning supports that conclusion. Otherwise, the commissioner would have the responsibility, but not the practical authority, to make decisions for the agency. Thus, the commissioner should not be required to defer to the decisions of a PBOI. It is unlikely, moreover, that the commissioner will give only "hip service" to the scientific judgments of a PBOI; as a practical matter, the board's scientific judgments will normally receive deference. In most cases, the commissioner will follow the board's recommendation because of the reputation of the board members, their specific expertise concerning the matters in dispute, the quality of their arguments, and the recognition that the integrity of the PBOI process will be undermined by arbitrary treatment of the board's conclusions. ${ }^{397}$

Moreover, even if the commissioner does not defer to the board's conclusions, the entire rationale of the PBOI does not "collapse." One important advantage of the PBOI process is that it produces a hearing record that fully and expertly delineates the issues to be decided. ${ }^{398}$ As a result, the PBOI contributes to the decisionmaking process by helping the commissioner appreciate the nature of the scientific issues. In cases with complex scientific issues, the commissioner would value this aspect of the PBOI process.

Finally, for cases in which the final FDA decision differs from the board's scientific judgnient, the commissioner could establish a procedural rule requiring the FDA to explain fully its reasons for rejecting the board's judgment. In the aspartame case, for example, the commissioner rejected the board's determination that the incidence of tumors in a control group of rats was imconsistent with the incidence of tumors that,

395. Brannigan, supra note 254 , at 198.

396. Note, supra note 255 , at 647 (footnote omitted).

397. Cf. R. PIERCE, S. SHAPIRO \& P. VerKuIL, supra note $8, \S 7.5$ (as a practical matter, degrec of deference given by federal courts varies with court's judgment whether deference is warranted by agency's expertise, actions, and explanations).

398. See supra note 269 and accompanying text. 
according to the scientific literature, would occur spontaneously. The commissioner found the board's interpretation of the scientific literature unjustified. ${ }^{399}$ The board had no special expertise concerning the scientific literature, because it was chosen for its expertise concerning neurotoxicity, not neuro-oncology. ${ }^{400}$ In this situation, the commissioner should have explained that, because of this mismatch between the dispute and the board's expertise, no deference to their judgment was appropriate.

Considered as a whole, the post-hearing process could work effectively. The depo-provera initial opinion indicates that PBOIs can produce decisions that exhaustively and rigorously consider the relevant issues. Furthermore, except for the delay in producing initial decisions, there are no significant probleuns at this stage of the process; the delay in the depo-provera case may have been atypical. As has been suggested here, inoreover, the FDA has several options available to it for speeding this stage of the process.

\section{The Future of the Public Board of INQuiry}

There lias been considerable interest in the FDA's experiences witl the PBOI because the process differs from the traditional means by which scientific input is obtamed. ${ }^{401}$ The FDA's experiences justify further experimentation with this type of process, botll at the FDA and at other agencies.

\section{A. The PBOI Process at the FDA.}

The FDA's experiences with the PBOI confirm tlie value of the "science court" idea for resolving issues of scientific judgment. ${ }^{402}$ Its scientific semmar format is conducive to scientific analysis and debate. As a practical matter, lowever, the costs of merging the PBOI and the regulatory process will limit the use of these boards. Although the two PBOIs that have been convened did engage in the type of scientific imquiry that the FDA anticipated at the hearing stage, ${ }^{403}$ delays and other problens in the pre- and post-hearing stages revealed the need to integrate the PBOI into the normal regulatory process. ${ }^{404}$ Many of these problems can be alleviated, but PBOIs will continue to be expensive. As a result, they will be cost-effective only in cases involving issues that call for so-

399. See supra notes 181-82 and accompanying text.

400. See supra notes $349-50$ and accompanying text.

401. See supra notes $109-12$ and accompanying text.

402. See supra notes $266-74$ and accompanying text.

403. See supra notes $320-21$ and accompanying text.

404. See supra notes $277-78,362-73$ and accompanying text. 
phisticated scientific judgment and stimulate great public interest. In those cases, the benefits of the PBOI-enhanced accuracy and legitimacy-are likely to outweigh the costs of the process.

Even if the use of the PBOI is limited, the process offers the FDA a unique option with several important advantages over the agency's advisory committee system. ${ }^{405}$ One key difference is that the PBOI convenes after the agency has decided whether to license a new drug or food additive. Because the PBOI can focus on the key issues in the agency's decision, it can serve as an independent check on the validity of that decision. Another key difference is that the PBOI emphasizes data analysis and is more accountable than other processes for its conclusions. As a result, the PBOI process enhances the accuracy and legitimacy of an agency's decisionmaking. ${ }^{406}$ Furthermore, because of its timing, the PBOI can lead to a scientific consensus on behalf of an agency's decision or a modification of it. 407

The FDA should also consider changing the format of the PBOI. For example, in heu of the current PBOI, persons entitled to a hearing could be offered the option of a "scientific seminar" hearing before the commissioner; independent scientists would participate in the hearing. This change would be more efficient because it would eliminate one step in the hearing process as well as many of the administrative burdens that have slowed the PBOI process. ${ }^{408}$ At the same time, it would still allow the FDA to obtam independent expert advice in a manner that would increase the accuracy and legitimacy of the decisionmaking process.

\section{B. The PBOI at Other Agencies.}

Based on the FDA's experiences, other agencies should consider use of the PBOI process. Like the FDA, agencies such as EPA, OSHA, and CPSC consider scientific evidence in determining whether chemicals are "safe." 409 Like the FDA, therefore, they make scientific judgments about the vahidity of animal, clinical, and epidemiological evidence. Moreover, the other agencies have the same options as the FDA for obtaiming independent scientific input. Health and safety agencies can seek scientific input through a hearing process, which is typically a form of rulemaking, ${ }^{410}$ or through advisory committees. ${ }^{411}$

405. See supra notes $322-28$ and accompanying text.

406. See supra notes $269-72$ and accompanying text.

407. See supra notes 131-32 and accompanying text.

408. See supra note 352.

409. See supra notes 29-31 and accompanying text.

410. See supra note 72 and accompanying text.

411. See supra notes $100-05$ and accompanying text. 
Other agencies could utilize the PBOI process in almost the same fashion as the FDA. To adapt the process to rulemaking, an agency could convene a PBOI to hear issues relevant to the rulemaking proceeding. The record of that proceeding, including the written opinion of the board, would become part of the rulemaking record. After the PBOI was completed, interested parties could place their responses in the record to rebut or support the PBOI decision. ${ }^{412}$

The PBOI offers other agencies the same advantages that the FDA has obtained. The PBOI would be convened after the agency had published a proposed rule. Unlike an advisory committee, the PBOI could address the specific issues raised by the proposed rule in a format that is more productive than that of an advisory committee meetmg. ${ }^{413}$ Because scientists could interact in a more "scientific" forum, the PBOI process would also be more likely than the rulemaking process to produce a thorough analysis of the scientific issues. ${ }^{414}$ Furthermore, the PBOI process would legitimate decisionmaking by subjecting the proposed rule to independent scrutiny. ${ }^{415}$ Finally, the PBOI could lead to scientific consensus for the agency's proposed rule or some variation of the rule. 416

OSHA's experience supports this view. ${ }^{417}$ In 1980, after a conventional rulemaking proceeding, OSHA adopted a general policy that specified the regulatory actions the agency would take if a substance was classified as a carcinogen. ${ }^{418}$ One reason it did so was to "precipitate a full-scale public shootout ... in which all interested parties could aid the agency in forging a policy that could serve as a model for all other government agencies." 419 The rule, however, "produced a cascade of opposition that was reflected not only in the [court] challenges . . . but in efforts in Congress and the executive branch . . . to effect changes."420 The rule has been withdrawn by OSHA on the ground that it was incoinpatable with the Supreme Court's interpretation of OSHA's powers. ${ }^{421}$

412. If the agency was required to hold a hearing as part of hybrid rulemaking, see supra notes 67-81 and accompanying text, the PBOI could serve to substitute for or augment the hearing.

413. See Ashford, supra note 101, at 166.

414. See supra note 402 and accompanying text.

415. See supra notes $272-74$ and accompanying text.

416. See supra notes 131-32 and accompanying text.

417. See Merrill, Comment, in LAw AND Science in Collaboration, supra note 1, at 105 (describing OSHA's poor experience with conventional rulemaking).

418. See Occupational Safety and Health Administration, Identification, Classification and Regulation of Potential Occupational Carcinogens, 45 Fed. Reg. 5002 (1980) (final rule).

419. McGarity, OSHA's Generic Carcinogen Policy: Rulemaking under Scientific and Legal Uncertainty, in LAW AND SCIENCE IN COLLABORATION, supra note 1, at 79.

420. Merrill, supra note 417, at 105.

421. See Schroeder \& Shapiro, supra note 32, at 1261-62. 
OSHA's unfavorable experience occurred in part because it was "attempting to define scientific parameters about which there remained wide dispute within the scientific community at large and certainly within the affected communities regulated by OSHA." 422 The agency's reliance on traditional informal rulemaking procedures in those circumstances may have doomed its efforts. The report for the National Center for Administrative Justice concluded:

The OSHA GCP rulemaking ... was not ... a shootout of science. ... "Any departures from the standard model [of traditional quasi-formal rulemaking] tended to be in the direction of judicialization rather than in the direction of more-informal [sic] attempts to invite the participation of scientists and facilitate the resolution of scientific issues." [No] shootout of science-an effective consensus gathering and evaluating of known science-has been held and fed into the GCP rule making. 423

The PBOI offers agencies the same advantages the FDA obtained, and although other agencies would experience some of the same problems as well, ${ }^{424}$ the PBOI may actually be more useful to them than to the FDA. Because the PBOI would not be responsible for writing a decision to replace the initial decision of an ALJ, ${ }^{425}$ these other agencies could limit the scope of the issues heard by the board to important questions of scientific judgment. As a result, the PBOI might be more costeffective in the rulemaking context for these agencies than it has been at the FDA.

If other agencies choose not to adopt a PBOI process, the FDA's experiences with the PBOI are still relevant. The PBOI process confirms the advantage of obtaining expert scientific advice in a setting where scientists can debate and act comfortably. Thus, health and safety agencies should continue to use advisory committees and should adopt the key elements of the PBOI process for those committees. The most important of those elements is the requirement that conclusions be reported in a specific and reviewable format. ${ }^{426}$

422. Merrill. supra note 417 , at 108.

423. Nyhart \& Carrow. Toward Better Resolution of Regulatory Issues Involving Science and Technology. in LAW AND SCIENCE IN COLLABORATION, supra note 1, at 290 (quoting Merrill, supra note 417 , at 106).

424. These include recruitment problems, see supra notes $277-90$ and accompanying text, and problems of delay. see supra notes $362-78$ and accompanying text.

425. See supra note 19 and accompanying text.

426. See supra note 25 and aceompanying text. 


\section{CONCLUSION}

The design of hearing procedures to resolve scientific disputes has been a significant problem for the administrative process in the last two decades. One fundamental change has already occurred: the hybrid hearing has been utilized for resolving such issues. Another fundamental change may now be on the horizon. The PBOI process differs from other methods of obtaining scientific input in three significant ways. First, unlike advisory committees, the PBOI has decisionmaking responsibility. Second, unlike most other hearing boards staffed by scientists, the members of the PBOI are not agency employees. Finally, the PBOI uses an informal hearing process. These changes result from recognizing that determining the safety of a chemical often requires difficult judgments that are scientific as well as regulatory.

In an analysis of whether a "scientific" or "adversarial" process better resolves issues of scientific judgment, the results are mixed. The FDA's experience does indicate that the PBOI can be the inore effective process, but at a higher price than the conventional approach. Thus, the PBOI is unlikely to be cost-effective except when it is used to resolve significant issues of scientific judgment.

No one should be surprised that the PBOI has not been an unquahfied success. The PBOI, or any similar scientific seminar process, must be incorporated into the normal, and adversarial, regulatory process. Problems are bound to arise when two such different methods of decisionmaking come together.

Many lawyers remain unconvinced of the merits of the PBOI. They object to the lack of adversarial procedures, and they beheve the PBOI is too costly. Although these concerns should be carefully considered, the FDA's experiences seein to contradict them. The PBOI process is only part of the regulatory process; the agency still retains the right and responsibility to make the final decisions, and the agency makes its decisions according to traditional adversarial procedures. As a result, the PBOI process appears to be a useful compromise: it allows scientists sufficient room to operate in an effective inanner without altering the ultimate method of agency decisionmaking.

The FDA's experience with the PBOI justifies continued experimentation there and at other agencies. The potential of the PBOI has been demonstrated, but its ultimate worth remains to be determined. Further experimentation would create a better record for calculating costs and benefits. At a tine when health and safety agencies face ever more difficult questions of scientific judgment, the PBOI 1nay emerge as an important improvement in the admmistrative process. 